Balance Sheet Strength and Bank Lending During the Global Financial Crisis

Tümer Kapan and Camelia Minoiu 
IMF Working Paper

Research Department

\title{
Balance Sheet Strength and Bank Lending During the Global Financial Crisis ${ }^{1}$
}

\author{
Prepared by Tümer Kapan and Camelia Minoiu
}

Authorized for distribution by Andrew Berg

May 2013

\section{This Working Paper should not be reported as representing the views of the IMF. The views expressed in this Working Paper are those of the author(s) and do not necessarily represent those of the IMF or IMF policy. Working Papers describe research in progress by the author(s) and are published to elicit comments and to further debate.}

\begin{abstract}
We examine the role of bank balance sheet strength in the transmission of financial sector shocks to the real economy. Using data from the syndicated loan market, we exploit variation in banks' reliance on wholesale funding and their structural liquidity positions in 2007Q2 to estimate the impact of exposure to market freezes during 2007-08 on the supply of bank credit. We find that banks with strong balance sheets were better able to maintain lending during the crisis. In particular, banks that were ex-ante more dependent on market funding and had lower structural liquidity reduced the supply of credit more than other banks. However, higher and better-quality capital mitigated this effect. Our results suggest that strong bank balance sheets are key for the recovery of credit following crises, and provide support for regulatory proposals under the Basel III framework.
\end{abstract}

JEL Classification Numbers: G21, G18, G01

Keywords: bank lending channel, wholesale funding, capital, net stable funding ratio, Basel III Author's E-Mail Addresses: tumer_kapan@fanniemae.com; cminoiu@imf.org

\footnotetext{
${ }^{1}$ This is a significantly expanded version of an earlier manuscript titled "Liquidity shocks, bank balance sheets, and international lending during 2007-08 crisis." We are thankful for helpful comments from Adrian Alter, Vladimir Borgy, Stijn Claessens, Giovanni Dell'Ariccia, Gaston Gelos, Iftekhar Hasan, Patrick Imam, Josef Korte, Luc Laeven, Mahvash Qureshi, Laura Valderrama, Jerome Vandenbussche, and seminar participants at the International Monetary Fund, Cleveland Fed, Central Bank of Ireland, 44th Annual Money, Macro and Finance Conference (Dublin, 2012), Macroeconomic and Financial Vulnerability Indicators in Advanced Economies Conference (Strasbourg, 2012), Yeditepe Symposium on International Banking and Finance (Istanbul, 2012), and the Bundesbank Conference "The Stability of the European Financial System and the Real Economy in the Shadow of the Crisis" (Dresden, 2013). Keith Miao provided excellent research assistance. The views expressed in this paper are those of the authors and do not necessarily reflect those of the institutions with which they are affiliated. All errors are our own.
} 


\section{Contents}

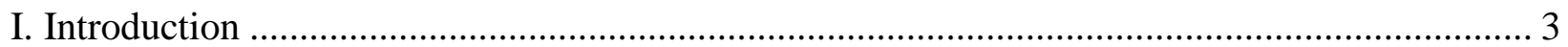

II. Balance Sheet Strength: Indicators and Hypotheses .............................................................. 6

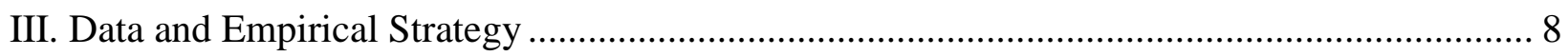

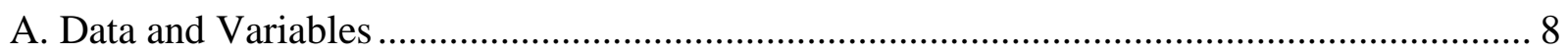

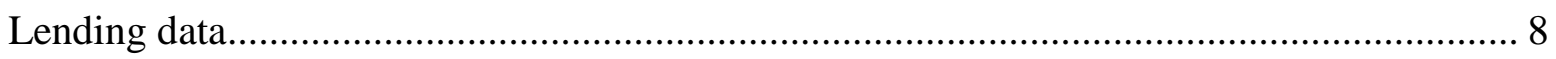

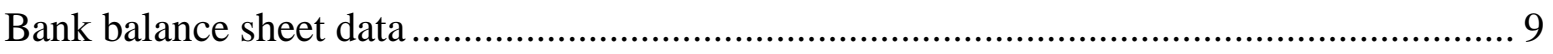

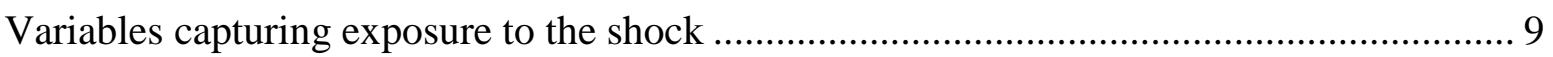

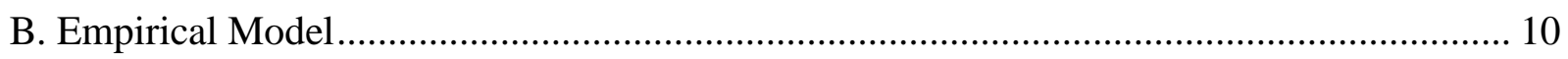

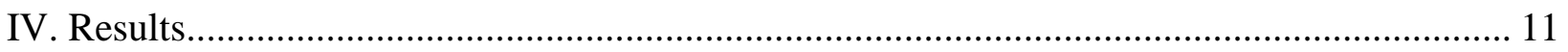

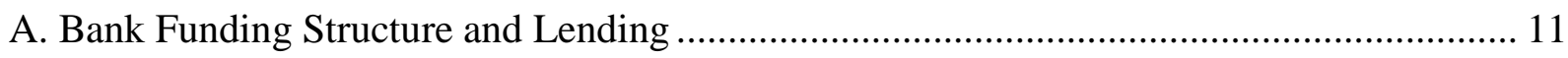

B. The Mitigating Effect of Bank Capital........................................................................ 12

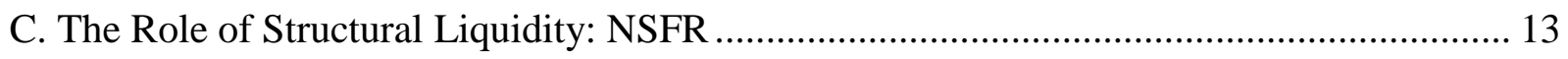

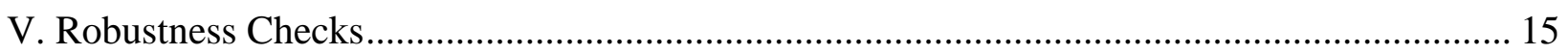

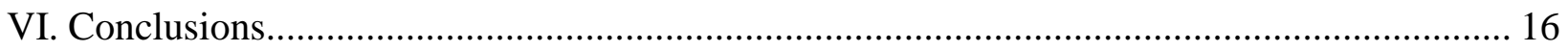

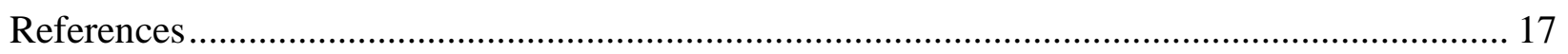

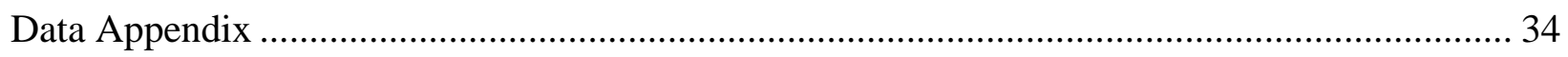

\section{List of tables}

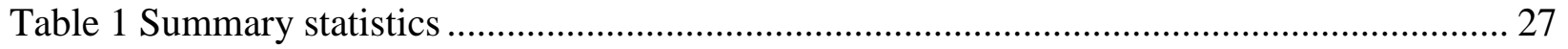

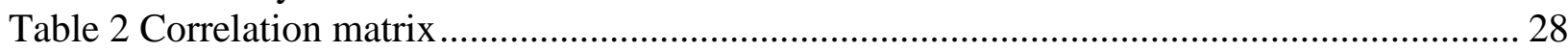

Table 3 Reliance on wholesale funding and bank lending: Baseline results ................................ 29

Table 4 Reliance on wholesale funding and bank lending: The mitigating impact of capital....... 30

Table 5 Structural liquidity (NSFR) and bank lending ................................................................. 31

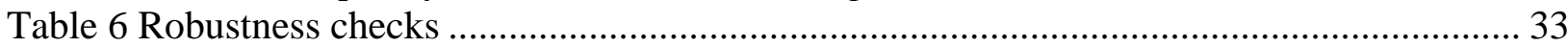

\section{List of figures}

Figure 1 Syndicated loan market: Total global issuance .......................................................... 22

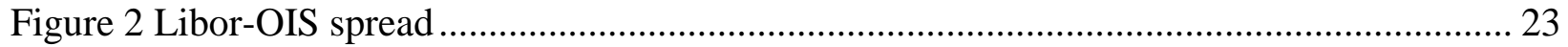

Figure 3 Trends in bank reliance on wholesale funding ............................................................. 24

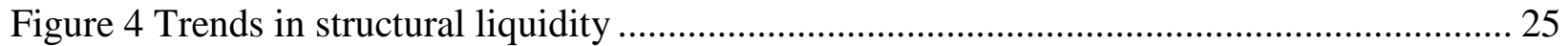

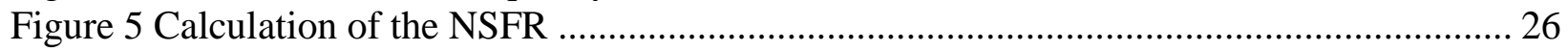

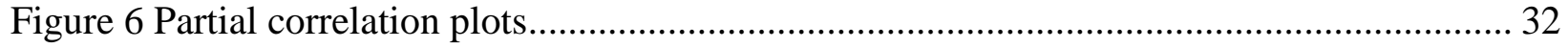




\section{INTRODUCTION}

An important legacy of the global financial crisis is a renewed regulatory effort aimed at safeguarding financial stability. This effort rests on the assumption that stronger capital and liquidity regulation would make banks more resilient to shocks and less likely to transmit them to the real economy by curtailing credit. In this paper, we examine the proposition that bank balance sheet strength matters for the extent to which banks reduce lending during a financial crisis. During the 2007-08 period, the cost of market funding faced by financial institutions increased to prohibitive levels, creating an unexpected liquidity shock. We investigate how banks' exposure to this shock influenced their subsequent lending decisions, and how it interacts with key balance sheet features such as capital. By quantifying the link between bank health and the supply of credit during the crisis, we also seek to inform the ongoing discussion on bank regulation under the Basel III framework.

Our analysis reveals that there is substantial variation in banks' ability to sustain lending during a financial crisis, and that this ability is largely determined by the strength of their balance sheets. We have three main results. First, we find that banks that relied more on market-based funding, hence were more vulnerable to liquidity shocks during the crisis, reduced their supply of credit more than other banks. ${ }^{2}$ This effect holds when we measure exposure to the shock with both standard measures of dependence on market-based funding and a complex measure of structural liquidity. Specifically, banks with a higher net stable funding ratio (NSFR), one of global liquidity standards proposed by the Basel Committee on Banking Supervision (BCBS), were better able to weather the crisis. Second, this effect was influenced by bank capitalization, and both the quantity and the quality of capital mattered. Banks that were exposed to shocks but were better capitalized, in the sense that they held more tangible common equity, reduced lending less than other banks with similar exposure to shocks. Third, there are complementarities between capital and structural liquidity, in that higher structural liquidity helps sustain lending only for well-capitalized banks.

To the best of our knowledge this is the first study that documents the role of balance sheet variables proposed under Basel III in sustaining post-crisis lending. We also explicitly examine the interaction between capital and structural liquidity. Since their introduction in 2010, the merits of the new regulations and their potential adverse effects for economic recovery have been intensely debated. A major concern is that, in the short run, tighter rules on capital and liquidity would lower banks' profitability and restrict their ability to extend credit, thus hamper growth. Basel III proponents argue instead that the new rules would make the banking system safer and

\footnotetext{
${ }^{2}$ A number of studies have documented this effect for the recent crisis, see, e.g., Ivashina, Scharfstein and Stein (2012), Cornett, McNutt, Strahan and Tehranian (2011) and Ivashina and Scharfstein (2010). See BCBS (2012) for a review on linkages between financial sector shocks and the real economy and policy implications.
} 
would benefit banks indirectly by lowering their cost of funding. ${ }^{3}$ We contribute to this debate by presenting systematic evidence on the effect of capital and liquidity on banks' ability to perform their intermediation function during times of stress. We find that higher and better-quality capital dampens the transmission of these shocks by vulnerable banks.

To perform the analysis we use loan-level data from the syndicated loan market - a large wholesale market that funds corporations and sovereigns worldwide. Syndicated loans are extended by a group of banks to a borrower under a single loan agreement. The banks participating in a syndicate may play different roles, ranging from the mandated or lead arranger who negotiates the loan and administers the payments, to the syndicate participants who only act as lenders. The syndicated loan market grew rapidly during the decade preceding the crisis, with more than USD 4.5 trillion worth of new issuances at its peak in 2007 (Figure 1). Ivashina and Scharfstein (2010) report that syndicated loan exposures represent about a quarter of total commercial and industrial loan exposures on US banks' balance sheets, and about a third for large US and foreign banks. Borrowers from both emerging markets and advanced economies tap into this market, although the latter account for most of the volume. Syndicated loans are also a key source of cross-border funding for firms from emerging market countries (de Haas and van Horen, 2013).

We analyze the lending behavior of more than 800 financial institutions vis-à-vis borrowers from 55 advanced economies and emerging markets during 2006-2010. Our empirical strategy is as follows. To relate the growth in syndicated loan volumes to the financial conditions of banks, we first partition the sample period into a "before," "shock," and "after" period. The "shock" window runs from the early signs of financial distress in the summer of 2007 to the fall of Lehman Brothers. We exploit the fact that liquidity conditions tightened substantially during the crisis as reflected in the Libor-OIS spread (Figure 2). We regress the change in total loan volume between the "before" and "after" periods on several indicators of balance sheet strength — both in levels and interactions - measured before the shock period. By focusing on the soundness of balance sheets before the crisis, we exploit the variation in banks' degree of exposure to turmoil in financial markets to identify the impact of the shocks on bank lending. We believe this variation is exogenous to banks' lending decisions because disruptions in funding markets caused by the US subprime crisis were unanticipated by banks.

An important challenge in our analysis is to separate changes in the demand from changes in the supply of credit, since both can be determined by the same aggregate shock. Our strategy is to retain in the sample only those borrowers that borrowed from the same lender both in the "before" and "after" periods for at least two lenders. Hence we exploit within-borrower variation

\footnotetext{
${ }^{3}$ For a summary of arguments and a quantitative impact assessment, see BCBS (2010a). King (2010) relates the new capital and liquidity requirements to bank lending spreads.
} 
in the exposure to the liquidity shock across banks and compare for each borrower the growth in lending from multiple banks that were differentially exposed to financial market turbulence (see Schnabl, 2012; Khwaja and Mian, 2008). Under the assumption that each borrower decreased his/her demand proportionately vis-à-vis its lenders, this strategy ensures that demand effects are purged from the estimates. This approach has been employed frequently in recent empirical studies of the bank lending channel. ${ }^{4}$

Our paper expands two related strands of literature. The first one focuses on the role of banking conditions in the transmission of financial sector shocks (in particular, monetary policy shocks) to the real economy (Jimenez, Ongena, Peydro and Saurina, 2012, 2011; Bernanke, 2007; Kashyap and Stein, 2000; Bernanke and Gertler, 1995; Bernanke and Blinder, 1988). ${ }^{5}$ Our first contribution to this strand is to use micro-data on lending to firms from a large number of countries and examine an international bank lending channel by which global banks facing tight conditions in funding markets reduce lending internationally. Our second contribution is to analyze the bank "balance sheet channel"-by which the strength of bank balance sheets influences the potency of the lending channel-from a novel perspective, one that combines both traditional and new measures of financial soundness.

The second strand of literature traces liquidity shocks in bank funding markets during the global financial crisis. ${ }^{6}$ Our analysis comes closest to Bonaccorsi di Patti and Sette (2012) who link balance sheet conditions to the provision of credit in Italy. The authors show that Italian banks that were more exposed to the interbank market or relied heavily on securitization prior to the subprime crisis curtailed lending more than other banks. Higher non-performing loans and lower profitability amplified this effect while capital did not act as a buffer. We extend this area of investigation (i) by taking a comprehensive view of balance sheet strength-including a complex measure of structural liquidity drawn from recent regulatory proposals, and allowing for interactions between capital and liquidity; and (ii) by testing the bank balance sheet channel using a large international sample of participants in the syndicated loan market.

\footnotetext{
${ }^{4}$ See, e.g., Irani (2012), de Haas and van Horen (2013, 2012), Correa, Sapriza, and Zlate (2012), Cetorelli and Goldberg (2011), and Iyer, Lopes, Peydro and Schoar (2010).

${ }^{5}$ See also Valencia and Verrier (2012) the how liquidity in the banking system influences the bank lending channel during times of uncertainty and Landier, Sraer and Thesmar (2013) on the role of banks' duration gap in the transmission of monetary policy shocks.

${ }^{6}$ This literature is divided roughly into two parts, with a first generation of papers analyzing the impact of US subprime crisis-related liquidity shocks on bank lending (e.g., de Haas and van Horen, 2013, 2012; Aiyar, 2012; Ivashina, Scharfstein and Stein, 2012; Dagher and Kazimov, 2012; Kapan and Minoiu, 2012; Cetorelli and Goldberg, 2011; Ivashina and Scharfstein, 2010; Iyer, Lopes, Peydro and Schoar, 2010; Allen, Hryckiewicz, Kowalewski and Tümer-Alkan, 2010) and a second generation of papers looking at the impact of the more recent European sovereign debt crisis on lending (e.g., Bofondi, Carpinelli and Sette, 2012; Popov and van Horen, 2012; Correa, Sapriza, and Zlate, 2012).
} 
We proceed as follows. In Section II we describe the indicators of balance sheet strength and our hypotheses. Section III introduces the data, variable definitions, and empirical framework. Section IV discusses the baseline results. Robustness checks are presented in Section V. Section VI concludes. The Data Appendix describes how we processed the data to obtain the final sample.

\section{BALANCE SHEET STRENGTH: INDICATORS AND HYPOTHESES}

We consider bank health indicators ranging from measures of funding structure that have been extensively scrutinized in the literature to the new structural liquidity measures considered by regulators. From the former group we focus on reliance on wholesale funding. From the latter group we consider the NSFR - a long-term liquidity requirement defined under Basel III (and further described in Section IV.C). We interpret these indicators, measured before the crisis, as proxies for banks' exposure to the heightened liquidity risk of 2007-08 when funding markets nearly shut down. In line with the literature, we expect reliance on market funding to be negatively associated with the supply of bank credit (see, e.g., Aiyar, 2012; Cornett, McNutt, Strahan and Tehranian, 2011; Ivashina and Scharfstein, 2010; Raddatz, 2010). Furthermore, we expect that banks with higher structural liquidity were less constrained during the crisis and hence better able to maintain lending.

Another dimension of bank health-the capital base-refers to a bank's ability to absorb losses. We focus on capital as a potential mitigating factor in the transmission of shocks through bank lending. Our hypothesis is that despite stress in funding markets, better capitalized banks have better been able to sustain the supply of syndicated lending. Two theoretical arguments guide us. The first one is related to the bank lending channel by which changes banks curtail lending when faced with a shortage of loanable funds because they cannot easily find alternative sources of funds (e.g., deposits). Capital plays a role here because during tight market conditions, well-capitalized banks may be able to raise debt under more favorable terms than other banks due to lower agency costs (Kishan and Opiela, 2000; Stein, 1998; Holmstrom and Tirole, 1997; Bernanke and Blinder, 1988). ${ }^{7}$ Second, an increase in the cost of funds erodes bank profits, which over time would result in lower bank capital if banks cannot reduce dividends substantially; therefore, banks may choose to forego profitable lending opportunities when interest rates rise to avoid ending up being undercapitalized in

\footnotetext{
${ }^{7}$ Goldberg, Kennedy and Miu (2010) link bank balance sheet strength to the cost of funds during the global financial crisis. They separate the 43 banks that submit interest rates for the calculation of the EURIBOR into three categories based on their financial health measured by Moody's Bank Financial Strength Rating. They find that stronger banks borrowed Euros during the crisis at lower average costs than medium- or lower-rated banks. Demirguc-Kunt and Huizinga (2010) show that banks reliant on non-deposit funding were perceived by equity market participants as riskier based on Z-scores (the number of standard deviations that a bank's rate of return on assets has to fall for the bank to become insolvent) and stock return volatility.
} 
the future. The latter is the so-called "bank capital channel" (Van den Heuvel, 2012, 2006, 2002; Bolton and Freixas, 2006).

It is well documented that capital is crucial for bank performance, especially during crises. Wellcapitalized banks are less likely to go bankrupt, lose market share, become unprofitable, and experience large declines in stock market capitalization. ${ }^{8}$ However, less is known about the impact of capital on lending during crises. Brei, Gambacorta and von Peter (2012) show that banks with higher regulatory capital ratios increase lending during normal times, but during crises they only do so when capital reaches a critical threshold. ${ }^{9}$ We shed light on this question by allowing for interactions between bank capital and measures of bank exposure to liquidity shocks. We find that well-capitalized banks reduce the supply of lending less than other banks with similar exposure to shocks, which suggests that bank capital plays a key role in sustaining lending during crises.

Reform of capital requirements plays a key role in the Basel III framework. Proposals for new regulation have been spurred by the fact that banks which required government support during the crisis met thresholds of capital adequacy before the crisis. Not only did capital ratios fail to raise concerns ahead of the crisis, they also failed to accurately predict the institutions that incurred the highest losses or ultimately failed (Haldane and Madouros, 2012; IMF, 2009; Mayes and Wood, 2009). Traditional risk-weighted capital buffers were uncorrelated with subprimerelated write-downs (Beltratti and Stulz, 2011) and with stock market performance (Das and Sy, 2012). ${ }^{10}$

Basel III proposes that regulatory capital be higher and that it include only capital instruments with high loss-absorbing ability such as common equity (see BCBS, 2010b; Blundell-Wignall and Atkinson, 2010). Under the Basel II definition regulatory capital includes, in addition to common equity, goodwill, minority interests, deferred tax assets, and investments in other financial institutions. Because some of these components have limited loss-absorbing ability, Basel III proposes removing them and retaining only common equity and equity-like debt instruments that can be used to write off losses. ${ }^{11}$ In light of these proposals, we consider

\footnotetext{
${ }^{8}$ See, e.g., Demirguc-Kunt, Detragiache, and Merrouche (forthcoming), Mariathasan and Merrouche (2012), Ng and Roychowdhury (2011), Berger and Bouwman (2009).

${ }^{9}$ In a related study, Berrospide and Edge (2010) focus on bank holding companies and find a small impact of changes in capital on lending; however, they do not distinguish between tranquil and crisis times.

${ }^{10}$ In a small sample of banks, Blundell-Wignall and Atkinson (2010) find a perverse positive link between pre-crisis Tier 1 ratio and crisis-related write-downs and credit losses, but a negative one between common equity and total losses.

${ }^{11}$ Basel III also proposes placing limits on a simple leverage ratio (defined as Tier 1 capital to total assets), and increasing the transparency and soundness of the risk weights used in computing regulatory capital ratios, especially for asset classes prone to sudden changes in liquidity. Mayes and Stremmel (2012) show that the simple leverage ratio outperforms risk-weighted measures of capital adequacy in predicting failure in a sample of US banks over
}

(continued...) 
alternative measures of capital such as the traditional Tier 1 and total regulatory capital, as well as tangible common equity - a measure that comes closer in spirit to Basel III. These measures help us qualify the hypothesis that bank capital helps sustain lending, as we anticipate that this effect will be stronger when we measure capital with common equity.

\section{DATA AND EMPIRICAl Strategy}

\section{A. Data and Variables}

\section{Lending data}

Loan-level data on close to 39,000 syndicated loan deals signed between January 2006 and March 2010 were obtained from Dealogic's Loan Analytics database. We divide the sample period into a "before," "shock," and "after" period. Our shock window, from July 2007 to September 2008, covers the period of intensification of the US subprime crisis. ${ }^{12}$ The six quarters preceding this window, January 2006-June 2007, are the "before" period and the six quarters following it, October 2008-March 2010, represent the "after" period. We drop all the loans signed during the shock window (July 2007-September 2008). Ideally we would like to work with a shock event, such as the Lehman bankruptcy, but doing so would require us to assume that banks did not adjust portfolios during the shock period. This assumption seems too strong. Therefore, we work with a window, which means that we focus on banks' exposure to a whole period of financial market turbulence rather than to a single event.

We obtain bank-level loan volumes, following the standard procedure in the literature, by splitting the syndicated loan amounts across syndicate participants, then aggregating them at the bank level (for each borrower). ${ }^{13}$ For about 30 percent of the loans in our sample, Loan Analytics reports the individual loan shares contributed by each syndicate member. For the remainder of the sample there is no such information so we use a regression model to predict the individual shares (out of sample). Specifically, we regress the log-shares against a comprehensive set of variables (including loan amount, syndicate size, dummies for year-quarters, loan currency, lender role, lender and borrower nationality, and borrower industry). The model performs well in-sample, with an adjusted R-squared of 74 percent. ${ }^{14}$ We then use the coefficients of the model to predict the shares out of sample and multiply them by the total loan amount to obtain individual loan amounts for each syndicate member.

1992-2012. Mariathasan and Merrouche (2012) document a similar pattern for the most recent crisis in a larger sample of almost 600 banks from 16 countries.

${ }^{12}$ Events that took place during this period include: the request for assistance by Bear Stearns hedge funds in June and July 2007; the announcement by French bank BNP Paribas that it suspends redemptions on its real estate investment funds in August 2007; and Countrywide's announcement in early 2008 of significant subprime-related losses for 2007.

${ }^{13}$ See, e.g., de Haas and van Horen (2012, 2013), Giannetti and Laeven (2012a, b), and Hale (2012).

${ }^{14}$ See Data Appendix for details. 
During the recent financial crisis, the syndicated market experienced a sharp adjustment. From its 2007 peak, the global issuance of syndicated loans fell by more than 40 percent in 2008 (Chui, Domanski, Kugler and Shek, 2010). ${ }^{15}$ However, most of this adjustment was on the extensive margin. The number of distinct borrowers dropped by a third in the post-Lehman period but the average loan amount remained almost unchanged (Kapan and Minoiu, 2012). Since there is little adjustment on the intensive margin, we should perform the analysis at a level of aggregation higher than the individual borrower (firm), so we define our borrowers to be country-specific industries (e.g., Germany-metal and steel, Spain-construction and building, Turkey-telecommunications, US-healthcare). ${ }^{16}$ Then we retain only those industries that borrowed from at least two banks both before and after the shock so we can control for borrower fixed effects and hence purge our estimates of the impact of simultaneous changes in demand.

\section{Bank balance sheet data}

In the next step, we match the financial institutions that act as lenders in Loan Analytics with balance sheet information from Bankscope. We match the two datasets using lender names and nationalities while making adjustments for name and ownership changes (see Data Appendix). In the final dataset, we have data on syndicated loans extended by 803 unique banks from 55 countries to firms from 448 country-specific industries in 48 countries. Our sample comprises a large and active cross-section of lenders in this market and is several times larger than in previous studies. ${ }^{17}$

\section{Variables capturing exposure to the shock}

The following measures computed with data from Bankscope are used to capture bank exposure to the liquidity shock. First, reliance on wholesale funding is measured with two alternative variables: non-deposit liabilities (as a share of total liabilities) and non-deposit funding (as a share of total funding). Summary statistics for all variables used in the empirical analysis are shown in Table 1. Figure 3 depicts long-term trends in average reliance on wholesale funding, and shows a significant increase prior to 2007-08 (measured both in aggregate terms and relative to the size of balance sheets) followed by a downward adjustment during the crisis. ${ }^{18}$

\footnotetext{
${ }^{15}$ The market recovered since then, with 2011Q2 new loan signings reaching pre-crisis levels (Gadanecz, 2011).

${ }^{16}$ This means that individual loan amounts are added up across firms at the country-industry level. There are maximum 25 industries per country. See Data Appendix for a list of industries and relative contributions to total borrowing.

${ }^{17}$ For instance, Giannetti and Laeven (2012a) analyze syndicated lending by 256 lead banks during 1997-2009, whereas de Haas and van Horen (2013) focus on 117 large participants in the market.

${ }^{18}$ Reliance on market funding remained high during 2009-10 (BCBS, 2012).
} 
In addition, we consider the NSFR, a measure of structural liquidity proposed under Basel III. This measure gauges the stability of a bank's funding sources relative to the liquidity profile of its assets. Unlike the two measures of funding structure introduced above, the NSFR combines elements from both the asset and liability sides of the balance sheet. The NSFR is aimed at more effectively monitoring bank soundness and alerting regulators to a potential build-up of vulnerabilities in the banking system. Table 2 shows that the NSFR is negatively correlated with measures of reliance on wholesale funding.

To compute an accurate NSFR measure (as defined in BCBS, 2010b), we need fine-grained balance sheet data. Since detailed data do not exist in Bankscope (nor in other public sources), we compute an approximation to the ratio that is based on a "stylized" balance sheet but that keeps in line with the Basel III formulas (See Section III.C for details). Figure 4 shows the evolution of the average NSFR in our sample of banks. The ratio improved steadily after the 2000-01 financial crisis, deteriorated in the run-up to the most recent crisis, and started improving again in 2008. In what follows, we estimate the impact of shock-exposure variables measured before the shock window (i.e., in 2007Q2) on the subsequent supply of bank credit.

\section{B. Empirical Model}

Our empirical model is given by $\Delta C_{i j k}=\alpha+\beta L_{i j}+\eta_{k}+\delta_{j}+\varepsilon_{i j k}(1)$, where $\Delta C_{i j k}$ is the log-change in syndicated bank credit (extended by bank $i$ in country $j$ to borrower $k$ ) and $L_{i j}$ is a proxy for the size of the bank-specific liquidity shock and is captured by our wholesale funding and structural liquidity measures. We assume that banks did not anticipate the US subprime crisis and therefore did not adjust lending in anticipation of the shocks (i.e., $\left.\operatorname{Corr}\left(L_{i j}, \varepsilon_{i j k}\right)=0\right)$. Note that if bank-specific shocks were correlated with demand, for instance if borrowers demanded less credit from banks that were more affected by the rise in the cost of funding, then we would have that $\operatorname{Corr}\left(L_{i j}, \eta_{k}\right) \neq 0$ and the OLS estimator of $\beta$ without $\eta_{k}$ would be biased (Khwaja and Mian, 2008). In order to control for demand, we include fixed effects at the borrower (countryspecific industry) level represented by $\eta_{k}$. Furthermore, to remove the possibility that our estimates are contaminated by exchange rate movements between the pre- and post-shock periods or by macroeconomic policies in banks' home countries, we add bank nationality effects $\delta_{j}$. As larger, more active banks in the syndicated loan market appear more frequently in our dataset, we control for the number of distinct borrowers by bank to make sure that these banks' characteristics do not drive our results.

We also estimate variants of Eq. (1) in which we control for a range of bank characteristics such as return on assets, non-performing loans, liquid-to-total assets ratio, bank size (total assets), risk profile (the ratio between risk-weighted assets (RWA) and total assets), and capital. In these specifications we add dummies for specialization (commercial, cooperative, savings, and 
investment bank, bank holding company, and others) and type of legal entity (independent company, single location bank, global owner, subsidiary). We estimate the statistical significance of the regression coefficients with standard errors that are clustered at the bank level.

\section{Results}

\section{A. Bank Funding Structure and Lending}

We begin with the baseline specification, in which we regress the growth rate in syndicated loan volume between the "before" and "after" periods against measures of the bank-specific exposure to the liquidity shocks. We start with standard measures of bank funding structure.

In Table 3 we report OLS estimates that do not control for shifts in demand (columns 1-4) and OLS estimates with borrower fixed effects that do (columns 5-10). The coefficient estimates on the measures of wholesale funding would be biased if the bank-specific shock were correlated with demand. This appears to be the case as we notice larger magnitudes in columns 1-4 than in columns 5-10. When we control for demand effects, the estimates show that banks that relied more heavily on market-based funding before the crisis reduced the supply of syndicated loans more than other banks. According to the estimated magnitudes, one percentage point increase in the share of non-deposit funding led to a decrease in the supply of syndicated credit by between 0.7 and 0.9 percent (across samples or sets of controls).

These results corroborate previous studies of the transmission of shocks through the bank lending channel, and provide evidence for the so-called "dark side" of wholesale funding (Acharya, Gale and Yorulmazer, 2011; Huang and Ratnovski, 2011), by which financial institutions reliant on market-based funding face the risk of creditor runs during crises. This effect has been examined previously in the literature, and our results confirm that it persists in a significantly larger cross-section of market participants than considered before.

However, the variety of business models in this expanded sample also raises concerns, e.g., the identified effect could be partly due to factors other than wholesale funding. It is possible that non-US banks that relied on market-based funding also had difficulties raising US dollars during the crisis. In that case, the results for these banks (columns 9-10) would capture both the effect of reliance on non-deposit funding and that of US dollars shortages (Kapan and Minoiu, 2012). However, earlier results alleviate this concern. Cornett, McNutt, Strahan and Tehranian (2011) and Ivashina and Scharfstein (2010) show that US banks, which arguably have the same degree of access to US dollar funding since their liabilities are denominated in dollars, were more likely to reduce the supply of lending during the crisis if they were more dependent on wholesale funding. In other words, there is evidence of a "wholesale funding effect" for US banks. In addition, in the early stages of the crisis when non-US banks faced dollar shortages, the Federal Reserve Bank introduced dollar liquidity swap lines with central banks such as the European 
Central Bank, the Bank of England, the Bank of Japan, and the Swiss National Bank. To the extent that these policies helped reduce the US dollar shortfall for non-US banks, as argued in Goldberg, Kennedy and Miu (2010), our baseline effect can be attributed to wholesale funding rather than confounding factors.

\section{B. The Mitigating Effect of Bank Capital}

An important question is whether the estimated negative impact of liquidity shocks on the supply of syndicated lending depends on capital adequacy - a key measure of bank health. To link bank capital to the supply of syndicated lending during the crisis, we consider three capital ratios: regulatory Tier 1 and total regulatory capital (Tier 1+Tier 2) divided by risk-weighted assets (RWA), both computed based on the Basel II regulation, and the tangible common equity ratio, ${ }^{19}$ which comes closer to the definition proposed under Basel III. ${ }^{20}$ To test if better capitalized banks mitigated the negative impact of the shock on credit supply, we interact these measures of capital adequacy with exposure to the liquidity shocks. In these specifications we control for banks' risk profile to allow for the possibility that better capitalized banks may be in a better position to take risks.

The estimates are shown in Table 4 . When we use the Tier 1 or total regulatory capital ratios to capture balance sheet strength (columns 1-8), we find that the extent to which exposed banks reduced their supply of credit is unrelated to their degree of capitalization (the estimated coefficients on the interaction terms are not statistically different from zero). However, the results are starkly different when we use tangible common equity (columns 9-12). Banks that were more vulnerable to liquidity shocks reduced the supply of syndicated loans less than other banks if they had more capital with high loss-absorbing potential. Evaluated at the sample mean of the ratio (6.90 percent), the coefficients suggest that with every percentage point increase in reliance on wholesale funding, the supply of credit fell by 0.65 to 0.82 percent (columns $9-12){ }^{21}$ Focusing on the estimates in column 10, an increase in bank capital by 1 standard deviation (4.29) from the sample mean (6.90 percent) would reduce the negative effect of the liquidity

\footnotetext{
${ }^{19}$ This is the ratio of (total shareholder equity minus preferred stock, goodwill, and intangible assets) to (total assets minus intangible assets).

${ }^{20}$ Unlike the regulatory ratios, which define capital as the buffer against losses that protects depositors, common equity is a concept of capital that is aligned with the interests of creditors. Based on this distinction, Acharya, Gujral, Kulkarni and Shin (2012) refer to common equity as "pure equity capital" or "market-determined capital requirement." In support of the view that common equity is the relevant concept for capital market participants, empirical studies find that common equity rather than regulatory ratios is what matters for stock market performance (Das and Sy, 2012).

${ }^{21}$ Column 10: $-1.392+0.083 * 6.90=-0.82$ percent.
} 
shock from 0.82 to 0.46 percent. Conversely, a reduction in bank capital by 1 standard deviation from the mean would amplify the effect of the liquidity shock to 1.18 percent. $^{22}$

These findings indicate that Basel II regulatory Tier 1 and total regulatory capital as measures of bank soundness are not helpful in gauging banks' ability to sustain lending in the face of liquidity shocks. ${ }^{23}$ They also support the Basel III proposal to raise the quantity and quality of regulatory capital, in particular those forms of capital with high loss-absorbing potential such as common equity.

\section{The Role of Structural Liquidity: NSFR}

Our last measure of balance sheet strength is the NSFR, an indicator of structural liquidity aimed at limiting reliance on short-term wholesale funding and creating incentives for banks to use stable funding sources (BCBS, 2010b). Unlike our earlier proxies, which only capture features of the liability side of the balance sheet, the NSFR refers to elements from both sides.

The NSFR represents the share of long-term illiquid assets funded with liabilities that are either long-term or stable (such as core deposits). It is calculated as NSFR $=\frac{\sum_{i} w_{i} L_{i}}{\sum_{j} w_{j} A_{j}}(2)$, where $L_{i}$ denotes liabilities, $A_{j}$ denotes assets, and $w_{i}$ and $w_{j}$ respectively represent weights (between 0 and 1, that may not add up to 1) assigned to different liabilities and assets. Larger weights are assigned to more illiquid assets and to more stable sources of funding. A higher NSFR indicates that the bank has stable funding sources relative to the liquidity profile of its assets, hence a lower liquidity risk.

Calculating an accurate NSFR requires detailed balance sheet information that is unavailable in Bankscope. We compute instead an approximate NSFR using the weights proposed in Vazquez and Federico (2012) and a stylized balance sheet based on Bankscope variables with maximum coverage (see Figure 5). The weights are chosen conservatively and in line with Basel III. On the asset side (denominator), since we do not have a breakdown of the loan portfolio by maturity, we assume that the entire portfolio requires stable funding, assigning it a weight of 1 . We do the

\footnotetext{
${ }^{22}$ In columns 9-12, the coefficients on the tangible common equity ratio are negative and statistically significant. However, we reject the null hypothesis that the marginal effect of capital is zero at the sample mean of non-deposit liabilities or funding.

${ }^{23}$ Another question of interest is whether it is the overstatement of true loss-absorbing potential (i.e., the numerator) or the mismeasurement of risk (i.e., the denominator) that drives this result. In specifications not reported here, we considered alternative capital ratios such as Tier 1 as a share of total assets; total regulatory capital as a share of total assets; and common equity as a share of RWA. With the exception of statistically weak results for the first ratio, we found that none of these capital adequacy measures had statistically significant coefficients in interaction with exposure to the shock.
} 
same for fixed assets and non-interest earning assets (other than "cash and due from banks" which receive zero weight). For other earning assets, Vazquez and Federico (2012) suggest a weight of 0.35 which is within the Basel III range. On the liability side (numerator), long-term funding, reserves, and equity are treated as stable sources of funding and given maximum weight. Sources of short-term funding such as deposits from banks, other deposits and short-term borrowings, and derivatives and trading liabilities receive zero weight. Customer deposits are seen as more stable than short-term funding and receive higher weights.

A number of studies calculate approximate NSFRs using stylized balance sheets and alternative weight factors. IMF (2011) finds that the average NSFR for large banks in 20 countries was below 100 percent in the run-up to the crisis, deteriorated further in 2008, and started to recover in 2009. King's (2012) NSFR estimates based on the balance sheet of a representative bank in each of 15 countries indicate that banks in 5 countries (including the US and Japan) met the minimum proposed threshold at end-2009. In a sample of 60 banks of which 13 failed during the crisis, IMF (2011) find that the NSFR is a relatively weak indicator of future liquidity problems. By contrast, in a significantly larger sample Vazquez and Federico (2012) show that banks with a higher NSFR were less likely to fail during the crisis.

We ask whether banks that survived the crisis and had higher structural liquidity going into it, were able to continue supplying credit in the syndicated loan market (or to reduce it to a lesser extent). To examine this question, we replace the wholesale funding variables in the baseline model with the continuous NSFR variable. The NSFR variable is log-transformed to allow for nonlinearities, in particular a declining benefit of a higher NSFR. ${ }^{24}$

The results for the full sample, shown in Table 5 (columns 1-2), suggest that for each percent increase in the NSFR, banks increased lending post-crisis by 0.43 to 0.46 percent (coefficients statistically significant at the conventional levels). Next we examine the interaction between capital and the NSFR by splitting the sample into high- and low-capital banks (columns 3-11). The estimated positive effect of the NSFR is larger in the subsample of well-capitalized banks, but only when capital is measured with the Tier 1 ratio or the tangible common equity ratio (columns 4, 10). Banks that had a better structural position before the crisis (i.e., had a higher NSFR) and were well capitalized, reduced credit supply less than other banks. This result holds when controlling for changes in demand and bank characteristics. By contrast, for poorlycapitalized banks, a higher NSFR did not translate into a better ability to sustain lending. These findings suggest that a stable funding structure relative to the bank's asset liquidity profile is only effective if the bank has a strong capital base, hinting at complementarities between capital and structural liquidity.

\footnotetext{
${ }^{24}$ Since we work with an imperfect measure of the NSFR, we refrain from comparing NSFR levels observed in our sample to the regulatory requirement of 100 percent.
} 
It is important to note here that our results for structural liquidity should be interpreted with some caution, as a perfectly accurate calculation of the NSFR requires fine-grained balance sheet data that are currently unavailable. We also note that the elasticities estimated so far are not driven by outliers. Figure 6 depicts partial correlation plots based on regressions from column 5 in Table 3 (Panel A) and column 1 in Table 5 (Panel B). We see that the relationship between the change in the volume of syndicated lending on the one hand, and the proxies for shock exposure on the other (while controlling for demand shifts), is quite general.

\section{Robustness Checks}

We conduct two robustness checks to ensure that our results stand up to an alternative set of covariates. These checks address two potential concerns.

A first concern is that the crisis-induced credit supply shock may have been specific to the syndicated loan market and not affected other types of lending. We believe this is unlikely as previous studies show that liquidity shocks affected all forms of lending. For instance, Dagher and Kazimov (2012) show that US banks with greater reliance on non-deposit funding reduced the supply of mortgage loans more than other banks. Raddatz (2010) and Allen, Hryckiewicz, Kowalewski and Tümer-Alkan (2010) report that banks that were more exposed to liquidity shocks in the interbank market reduced total lending. In our context, one way to address any residual concern is by controlling for the change in total loans between the pre- and post-shock periods, with the caveat that we are unable to control for shifts in demand that may have simultaneously taken place in other credit markets.

A second concern relates to the possibility that the supply of credit may have better been sustained by strong banks due to their enhanced ability to acquire other banks and hence expand their balance sheets during the crisis. If this were true, then the coefficients on our variables of interest, measured before the crisis, may incorporate this effect. We address this possibility by controlling for the change in total assets between the pre- and post-shock period. The estimates are shown in Table 6 (columns 1-7 for the first concern, columns 8-14 for the second).

Overall, the specifications suggest our results are robust to including these additional covariates. The specifications with funding structure as a proxy for exposure to the shocks indicate that a one percentage point increase in pre-crisis reliance on wholesale funding led to a decline in the supply of syndicated loans of $0.6-0.7$ percent (statistically significant at the 1 percent level) (columns 1-2, 8-9). This negative impact was cushioned by higher tangible common equity (columns 3-4, 10-11) and is robust to using structural liquidity as the indicator of vulnerability

to shocks (columns 5-7, 12-14), with the caveat that the estimated coefficients on the NSFR are only statistically significant at the 14.5 and 12.1 percent levels, respectively (columns 5, 12). 


\section{Conclusions}

Using loan-level data for a large sample of financial institutions lending in the syndicated loan market, we estimated the impact of liquidity shocks to market-based funding during the recent crisis on the subsequent supply of credit. We focused on the role of bank balance sheets, in particular, capital and structural liquidity, in influencing the transmission of shocks through the bank lending channel. Our main contribution has been to take a novel look at what constitutes a strong bank balance sheet drawing on recent proposals for bank regulation.

We found that banks that relied more heavily on wholesale funding and had lower structural liquidity, hence were more exposed to liquidity shocks during the crisis, reduced syndicated lending more than other banks. However, bank capital played a cushioning role: bettercapitalized banks that were exposed to the shocks decreased their supply of credit less than other banks. The evidence that bank equity acts as a buffer is stronger when capitalization is measured with tangible common equity-a measure of capital that comes close to the Basel III proposal. By contrast, the Tier 1 and total regulatory capital ratios are less useful for distinguishing among banks according to their ability to sustain lending. These results underscore the importance of bank capital for the recovery of credit after crises and lend support to recent proposals to raise the regulatory standard on both quantity and quality. In addition, we found that banks which had lower structural liquidity before the crisis, hence were more vulnerable to financial market turmoil, reduced lending more than other banks. We conclude that banks with stronger balance sheets from the perspective of Basel III were better able to perform their intermediation function during the recent crisis.

Our results lend support to Disyatat's (2011) re-interpretation of the traditional bank lending channel in modern financial systems in which banks rely heavily on market-based funding. In his framework, the bank lending channel works mainly through the impact of monetary policy on bank balance sheet strength. Disyatat (2011) also shows that there are threshold effects: for banks with capital above a certain level, small negative shocks to asset values are fully absorbed into the system and are not passed on to the real economy through reduced lending. Below that critical level, the same shock leads to a reduction in the equilibrium amount of lending. In Disyatat's framework, as in our analysis, banks can act either as amplifiers or absorbers of financial sector shocks depending on their financial strength. 


\section{REFERENCES}

Acharya, V., Gale, D. and T. Yorulmazer, 2011, "Rollover risk and market freezes," Journal of Finance, Vol. 66, pp. 1177-1209.

Acharya, V., Gujral, I., Kulkarni, N., and H. Shin, 2012, "Dividends and bank capital in the financial crisis 2007-09," NYU Stern School of Business, Department of Finance, mimeo.

Aiyar, S., 2012, "From financial crisis to great recession: The role of globalized banks," American Economic Review Papers \& Proceedings, Vol. 102(3), pp. 225-230.

Allen, F., Hryckiewicz, A., Kowalewski, O. and G. Tümer-Alkan, 2010, “Transmission of bank liquidity shocks in loan and deposit markets: The role of interbank borrowing and market monitoring," Wharton Financial Institutions Center, Working Paper No. 10-28.

Basel Committee on Banking Supervision, 2010a, "An assessment of the long-term economic impact of stronger capital and liquidity requirements," BIS Report, August. Available on: http://www.bis.org/publ/bcbs173.pdf (accessed on April 3, 2013).

Basel Committee on Banking Supervision, 2010b, "Basel III: International framework for liquidity risk measurement, standards and monitoring," BIS Report, December. Available on: http://www.bis.org/publ/bcbs188.pdf (accessed on April 3, 2013).

Basel Committee on Banking Supervision, 2012, "The policy implications of transmission channels between the financial system and the real economy," BIS Working Paper No. 20.

Beltratti, A. and R. Stulz, 2011, "The credit crisis around the globe: Why did some banks perform better?" Journal of Financial Economics, Vol. 105(1), pp. 1-17.

Berger, A.N. and C. H. S. Bouwman, 2009, "Bank capital, survival, and performance around financial crises," mimeo, Wharton Financial Institutions Center, University of Pennsylvania.

Bernanke, B. S., 2007, "The financial accelerator and the credit channel," Speech delivered at The Credit Channel of Monetary Policy in the Twenty-first Century Conference, Federal Reserve Bank of Atlanta, GA, June 15.

Bernanke, B. S. and M. Gertler, 1995, "Inside the black box: The Credit Channel of Monetary Policy," Journal of Economic Perspectives, Vol. 9(4), pp. 27-48.

Bernanke, B. S. and A. S. Blinder, 1988, "Money, credit, and aggregate demand," American Economic Review, Vol. 82, pp. 901-921.

Berrospide, J. M. and R. M. Edge, 2010, "The effects of bank capital on lending: What do we know, and what does it mean?" Journal of International Central Banking, Vol. 6(4).

Blundell-Wignall, A. and P. Atkinson, 2010, "Thinking beyond Basel III: Necessary solutions for capital and liquidity," OECD Journal: Financial Market Trends, Vol. 2010 (1), pp. 1-22. 
Bofondi, M., Carpinelli, L. and E. Sette, 2012, “Credit supply during a sovereign crisis," mimeo, Economic Research Department, Bank of Italy.

Bolton, P. and X. Freixas, 2006, "Corporate finance and the monetary transmission mechanism," Review of Financial Studies, Vol. 19(3), pp. 829-870.

Bonaccorsi di Patti, E. and E. Sette, 2012, "Bank balance sheets and the transmission of financial shocks to borrowers: Evidence from the 2007-08 crisis," Bank of Italy Working Paper No. 848.

Brei, M., Gambacorta, L. and G. von Peter, 2012, "Rescue packages and bank lending," Journal of Banking and Finance, Vol. 37(2), pp. 490-505.

Cetorelli, N. and L. Goldberg, 2011, "Global banks and the international shock transmission: Evidence from the crisis," IMF Economic Review, Vol. 59(1), pp. 41-76.

Chui, M., Domanski, D., Kugler, P. and J. Shek, 2010, "The collapse of international bank finance during the crisis: Evidence from syndicated loan markets," BIS Quarterly Review, September, pp. 39-49.

Cornett, M. M., McNutt, J. J., Strahan, P. E., and H. Tehranian, 2011, “Liquidity risk management and credit supply in the financial crisis," Journal of Financial Economics, Vol. 101(2), pp. 297-312.

Correa, R., Sapriza, H. and A. Zlate, 2012, "Liquidity shocks, dollar funding costs, and the bank lending channel during the European sovereign crisis," International Finance Discussion Paper 1059, Board of Governors of the Federal Reserve System (US).

Dagher, J. and K. Kazimov, 2012, "Banks' liability structure and mortgage lending during the financial crisis," IMF Working Paper No. 12/155.

Das, S. and A. Sy, 2012, "How risky are banks' risk weighted assets? Evidence from the financial crisis," IMF Working Paper No. 12/36.

De Haas, R. and N. Van Horen, 2013, "Running for the exit: International bank lending during a crisis," Review of Financial Studies, Vol. 26(1), pp. 244-285.

De Haas, R. and N. Van Horen, 2012, "International shock transmission after the Lehman Brothers collapse: Evidence from syndicated lending," American Economic Review Papers \& Proceedings, Vol. 102 (3), pp. 231-237.

Demirguc-Kunt, A., E. Detragiache, and O. Merrouche, forthcoming, “"Bank capital: Lessons from the crisis," Journal of Money, Credit and Banking.

Demirguc-Kunt, A. and H. Huizinga, 2010, "Are banks too big to fail or too big to save? International evidence from equity prices and CDS spreads," CEPR Discussion Paper No. 7903. 
Disyatat, P., 2011, “The bank lending channel revisited," Journal of Money, Credit and Banking, Vol. 43(4), pp. 711-734.

Fitch Ratings and Bureau van Dijk, 2009, "The Fitch Universal Format on Bankscope," mimeo, London, April. Available on: http://www.bvd.co.uk/bankscope/bankscope.pdf (accessed on April 3, 2013).

Gadanecz, B., 2011, "Have lenders become complacent in the market for syndicated loans? Evidence from covenants," BIS Quarterly Review, September, pp. 26-27.

Giannetti, M. and L. Laeven, 2012a, "The flight home effect: Evidence from the syndicated loan market during financial crises," Journal of Financial Economics, Vol. 104(1), pp. 23-43.

Giannetti, M. and L. Laeven, 2012b, "Flight home, flight abroad, and international credit cycles," American Economic Review Papers \& Proceedings, Vol. 102(3), pp. 219-224.

Goldberg, L., C. Kennedy, and J. Miu, 2010, “Central Bank Dollar Swap Lines and Overseas Dollar Funding Costs,” NBER Working Paper No. 15763.

Haldane, A. and V. Madouros, 2012, "The dog and the frisbee," Paper presented at the Federal Reserve Bank of Kansas City's 36th Economic Policy Symposium "The changing policy landscape," August 31.

Hale, G., 2012, "Bank relationships, business cycles, and financial crises," Journal of International Economics, Vol. 88(2), pp. 312-325.

Holmstrom, B. and J. Tirole, 1997, "Financial intermediation, loanable funds, and the real sector," Quarterly Journal of Economics, Vol. 112, pp. 663-691.

Huang, R. and L. Ratnovski, 2011, "The dark side of bank wholesale funding," Journal of Financial Intermediation, Vol. 20(2), pp. 248-263.

International Monetary Fund, 2011, Global Financial Stability Report, Chapter 2 "How to address the systemic part of liquidity risk," April (Washington: International Monetary Fund).

International Monetary Fund, 2009, Global Financial Stability Report, Chapter 3 "What constitutes "systemic risk"?" April (Washington: International Monetary Fund).

Irani, R. M., 2012, "Bank health and corporate liquidity provision," mimeo, College of Business, University of Illinois at Urbana-Champaign.

Ivashina, V., Scharfstein, D. S., and J. C. Stein, 2012, "Dollar funding and the lending behavior of global banks," NBER Working Paper No. 18528. 
Ivashina, V. and D. S. Scharfstein, 2010, "Bank lending during the financial crisis of 2008," Journal of Financial Economics, Vol. 97, pp. 319-338.

Iyer, R., Lopes, S., Peydro, J. and A. Schoar, 2010, "The interbank liquidity crunch and the firm credit crunch: Evidence from the 2007-09 crisis," Universitat Pompeu Fabra, Department of Economics and Business, mimeo.

Jimenez, G., Ongena, S., Peydro, J.-L., and J. Saurina, 2012, "Credit supply: identifying balancesheet channels with loan applications and granted loans," American Economic Review, Vol. 102(5), pp. 2301-2326.

Jimenez, G., Ongena, S., Peydro, J.-L., and J. Saurina, 2011, "Credit supply vs. demand: Bank and firm-balance sheet channels in good and crisis times," mimeo, Department of Economics, Universitat Pompeu Fabra.

Kapan, T. and C. Minoiu, 2012, "Liquidity shocks and the supply of credit after the 2007-08 crisis," mimeo, International Monetary Fund.

Kashyap, A. K., and J. C. Stein, 2000, "What do a million observations on banks say about the transmission of monetary policy?" American Economic Review, Vol. 90(3), pp. 407-428.

Khwaja, A. I. and A. Mian, 2008, "Tracing the impact of bank liquidity shocks: Evidence from an emerging market," American Economic Review, Vol. 98(4), pp. 1413-1442.

King, M. R., 2012, "The Basel III net stable funding ratio and bank net interest margins," mimeo, Richard Ivey School of Business, University of Western Ontario.

King, M. R., 2010, "Mapping capital and liquidity requirements to bank lending spreads," BIS Working Paper No. 324.

Kishan, R. P. and T. P. Opiela, 2000, "Bank size, bank capital, and the bank lending channel," Journal of Money, Credit and Banking, Vol. 32(1), pp. 121-141.

Landier, A., Sraer, D. and D. Thesmar, 2013, "Banks exposure to interest rate risk and the transmission of monetary policy,” NBER Working Paper No. 18857.

Longaberger, H., 2011, "Product Review of BvD Bankscope." Available on: http://www.bvdinfo.com/BvD/media/General/Full-Bankscope-Review.pdf (accessed on April 3, 2013).

Mariathasan, M. and O. Merrouche, 2012, "The manipulation of Basel risk-weights: Evidence from 2007-10," University of Oxford Department of Economics Discussion Paper No. 621.

Mayes, D. G., and H. Stremmel, 2012, "The effectiveness of capital adequacy measures in predicting bank distress," University of Auckland, mimeo. 
Mayes, D. G., and G. E. Wood, 2009, "The Northern Rock Crisis in the UK," in T. Congdon, C. A. E. Goodhart, R. A. Eisenbeis, G. G. Kaufman, P. Hamalainen, R. M. Lastra, D. T. Llewellyn, D. G. Mayes, G. Wood, A. Milne \& M. Onado (Eds.), The Failure of Northern Rock-A Multidimensional Case Study: SUERF-The European Money and Finance Forum.

Ng, J. and S. Roychowdhury, 2011, "Loan loss reserves, regulatory capital, and bank failures: Evidence from the recent economic crisis," Boston College Carroll School of Management, mimeo.

Popov, A. and N. van Horen, 2012, "The impact of sovereign debt exposure on bank lending: Evidence from the European debt crisis," mimeo, Dutch National Bank.

Raddatz, C., 2010, "When the rivers run dry: Liquidity and the use of wholesale funds in the transmission of the U.S. subprime crisis," World Bank Policy Research Working Paper no. 5203.

Schnabl, P., 2012, "The international transmission of bank liquidity shocks: Evidence from an emerging market," Journal of Finance, Vol. 67(3), pp. 897-932.

Stein, J. C., 1998, “An Adverse-Selection Model of Bank Asset and Liability Management with Implications for the Transmission of Monetary Policy," RAND Journal of Economics, Vol. 29(3), pp. 466-486.

Valencia, F. and J. Verrier, 2012, “Aggregate uncertainty and the supply of credit," mimeo, International Monetary Fund.

Van den Heuvel, S., 2012, "Banking conditions and the effects of monetary policy: Evidence from US states," BE Journal of Macroeconomics: Advances, Vol. 12(2).

Van den Heuvel, S., 2006, "The bank capital channel of monetary policy," 2006 Meetings Papers 512, Society for Economic Dynamics.

Van den Heuvel, S., 2002, “Does bank capital matter for monetary transmission?” Federal Reserve Bank of New York Economic Policy Review, Vol. 8(1), pp. 259-265.

Vazquez, F. and P. Federico, 2012, "Bank funding structures and risk: Evidence from the global financial crisis," IMF Working Paper No. 12/29. 


\section{Tables and Figures}

\section{Figure 1 Syndicated loan market: Total global issuance}

Notes: The chart depicts total syndicated lending during 1992-2010. The blue line is based on almost 40,000 syndicated loans extended between Jan 2005 and Dec 2010, from Loan Analytics. The red line, for comparison, shows data from the BIS Quarterly Review March 2012, Table 10 representing "Signed international syndicated credit facilities (with maturity less than 3 months)" and available on http://www.bis.org/statistics/secstats.htm. The difference between the two lines reflects the exclusion by the BIS of loans with maturity greater than 3 months. Data sources: Loan Analytics, BIS.

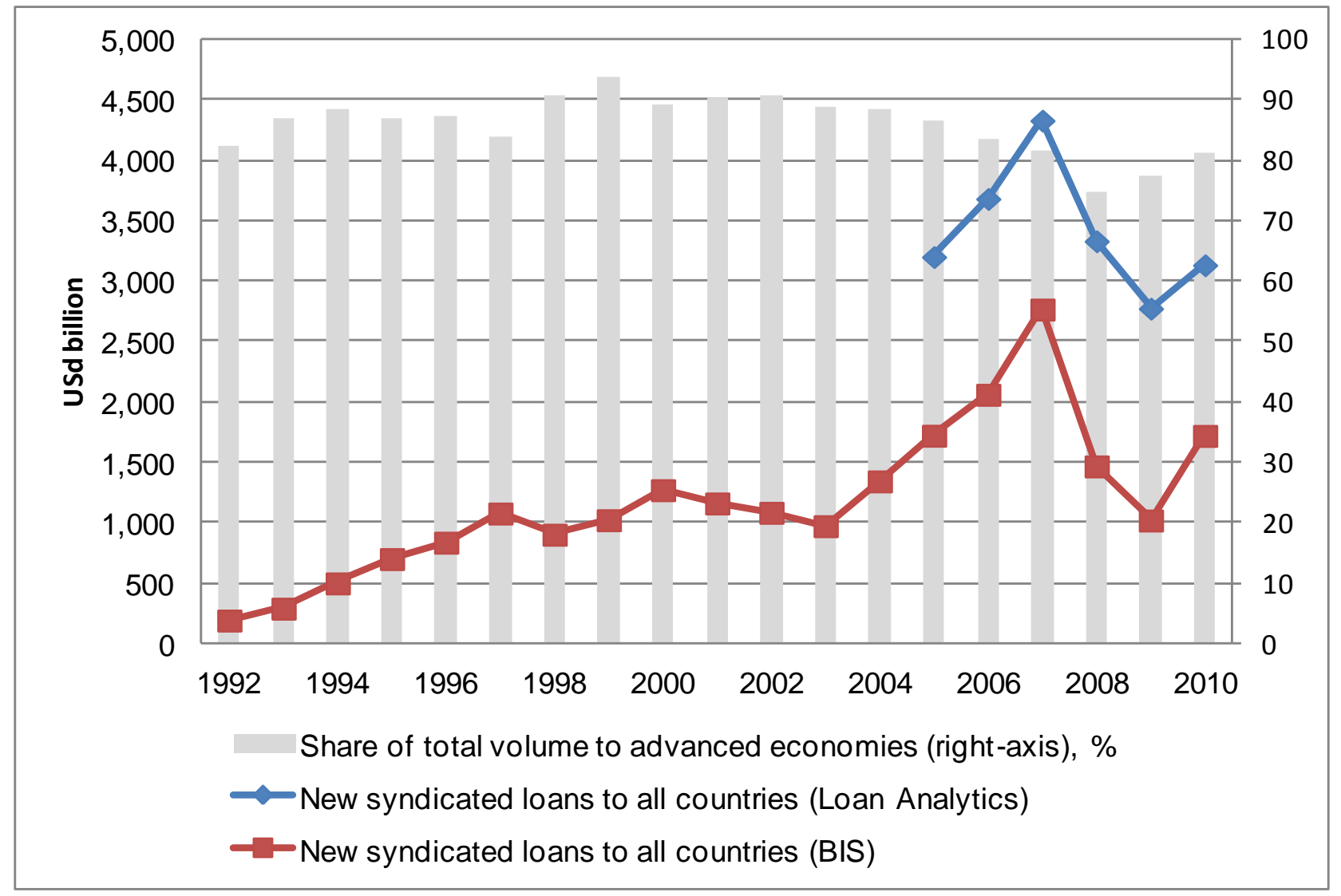




\section{Figure 2 Libor-OIS spread}

Notes: The chart shows the three-month dollar Libor-OIS spread over 2004-2011. The "before" period runs from January 2006 to June 2007. The "after" period runs from October 2008 to March 2010. The "shock" window (July 2007 to September 2008) between the two refers to the period of intensification of the subprime crisis. Data sources: Based on data from Bloomberg.

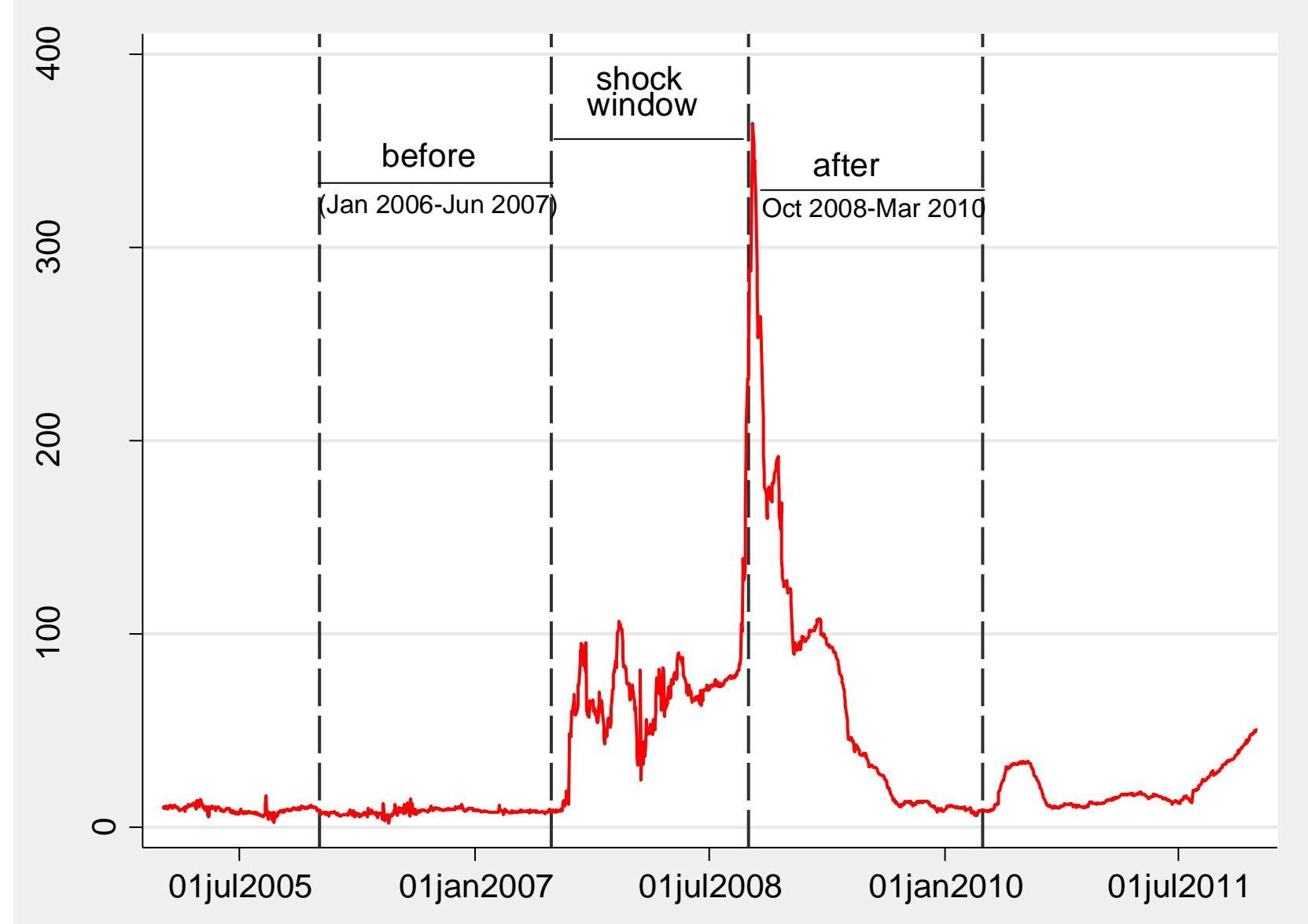




\section{Figure 3 Trends in bank reliance on wholesale funding}

Notes: The charts show the average wholesale funding during 1999-2010, in current USD billion (Panel A) and relative to the size of the balance sheet (Panel B) in the final sample of banks. Data sources: Loan Analytics and Bankscope.

Panel A

(USD billion)

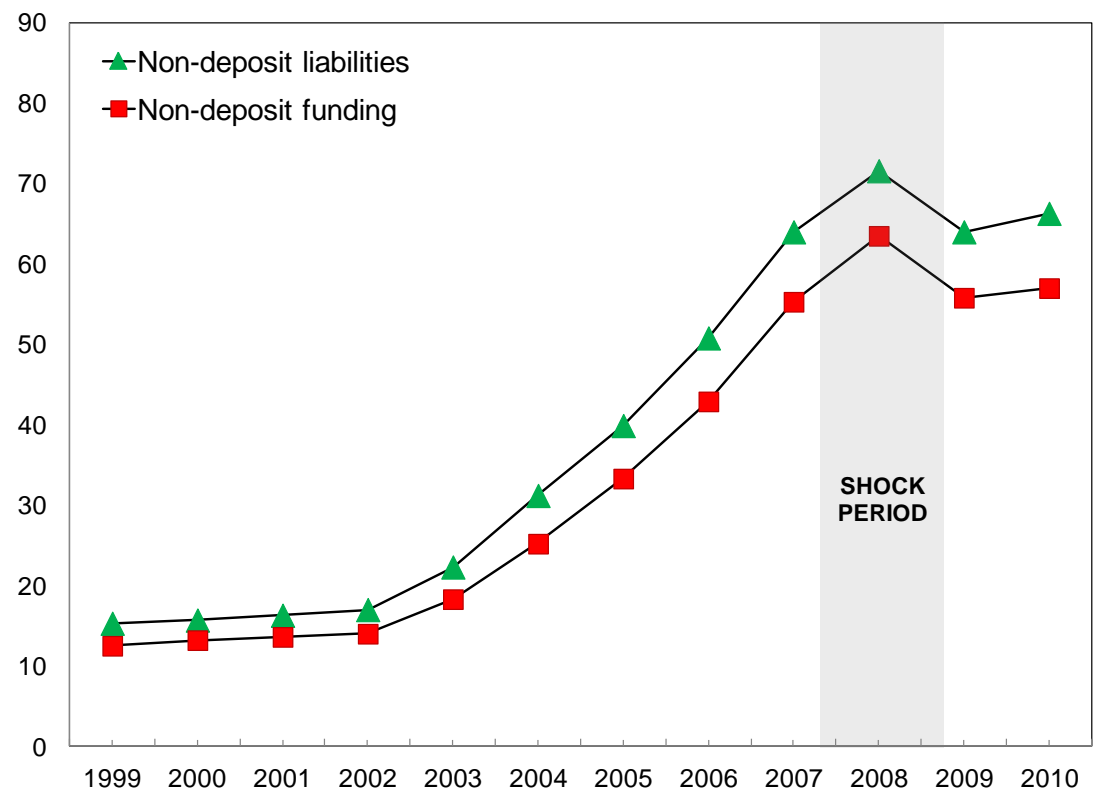

Panel B

(percent)

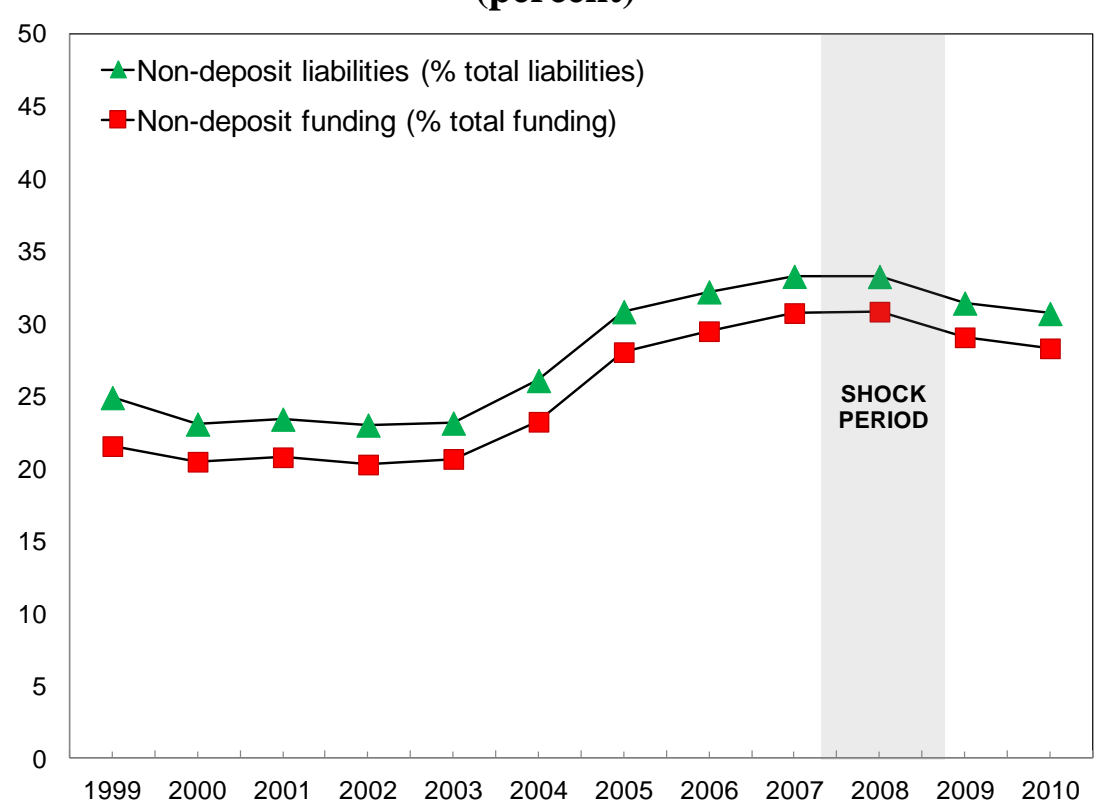




\section{Figure 4 Trends in structural liquidity}

Notes: The chart shows the average NSFR during 1999-2010 (in percentage) in the final sample of banks. Data sources: Loan Analytics and Bankscope.

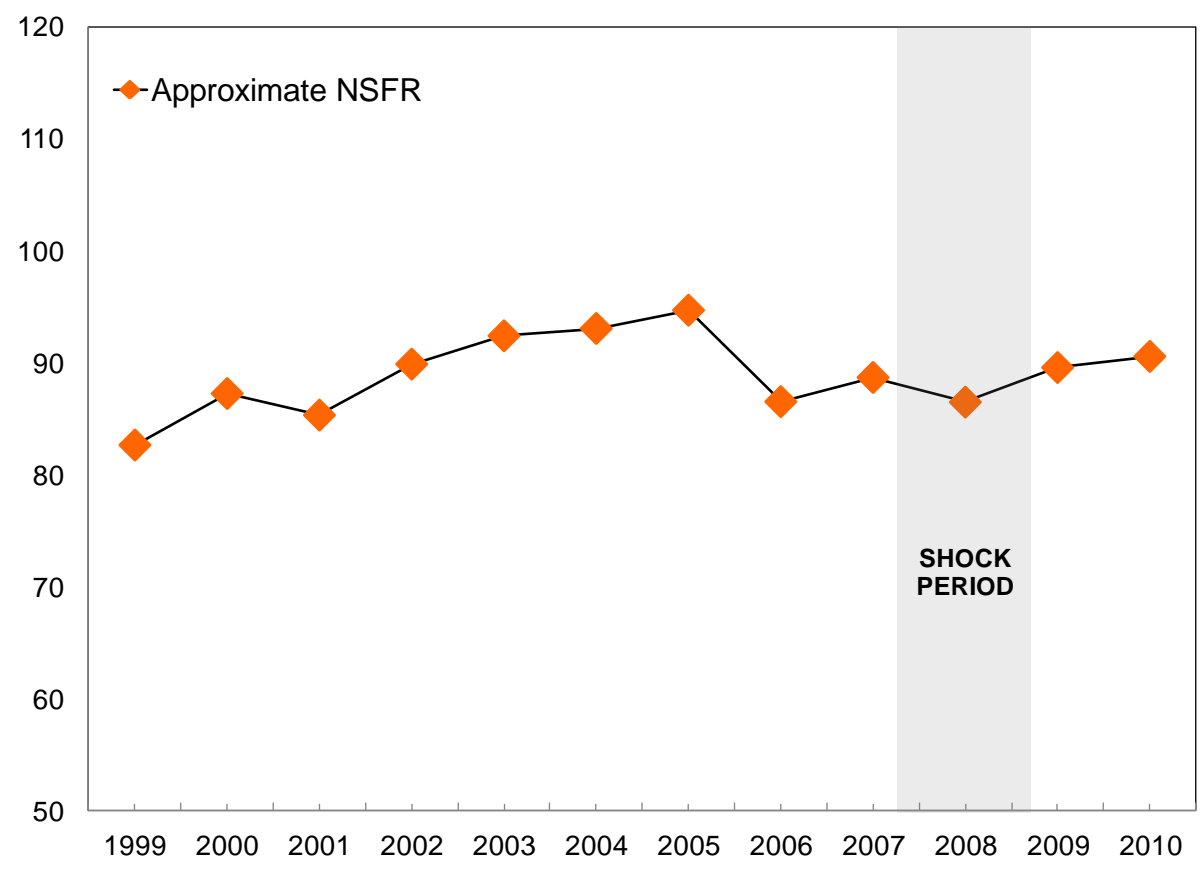




\section{Figure 5 Calculation of the NSFR}

Notes: Stylized bank balance sheet (based on variables available in Bankscope) and weights used in the calculation of the NSFR. Source: Reproduced with permission from Vazquez and Federico (2012).

\begin{tabular}{|c|c|c|c|c|c|}
\hline \multicolumn{2}{|r|}{ Assets } & \multicolumn{2}{|l|}{ Weights } & Liabilities & Weights \\
\hline 1 & \begin{tabular}{|l|} 
Total earning assets \\
\end{tabular} & $100 \%$ & 1 & Deposits and short-term funding & \\
\hline $1 . \mathrm{A}$ & Loans & & 1.A & Customer deposits & \\
\hline 1.A.1 & Total customer loans & & 1.A.1 & Customer deposits-current & $85 \%$ \\
\hline & Mortgages & & 1.A.2 & Customer deposits-savings & $70 \%$ \\
\hline & Other mortgage loans & & 1.A.3 & Customer deposits-term & $70 \%$ \\
\hline & Other consumer/retail loans & & $1 . \mathrm{B}$ & Deposits from banks & $0 \%$ \\
\hline & $\begin{array}{l}\text { Corporate \& commercial loans } \\
\text { Other loans }\end{array}$ & & 1.C & Other deposits and short-term borrowings & $0 \%$ \\
\hline 1.A.2 & Reserves for impaired loans/NPLs & & 2 & Other interest-bearing liabilities & \\
\hline 1.B. & Other earning assets & $35 \%$ & 2.A & Derivatives & $0 \%$ \\
\hline 1.B. 1 & Loans and advances to banks & & 2.B & Trading liabilities & $0 \%$ \\
\hline 1.B.2 & Derivatives & & 2.C & Long-term funding & $100 \%$ \\
\hline 1.B.3 & Other securities & & 2.C.1 & Total long-term funding & $100 \%$ \\
\hline & Trading securities & & & Senior debt & \\
\hline & Investment securities & & & Subordinated borrowing & \\
\hline 1.B.4 & Remaining earning assets & & & Other funding & \\
\hline 2 & Fixed assets & $100 \%$ & 2.C.2 & Preferred shares and hybrid capital & $100 \%$ \\
\hline 3 & Non-earning assets & & 3 & Other (non-interest bearing liabilities) & $100 \%$ \\
\hline 3.A & Cash and due from banks & $0 \%$ & 4 & Loan loss reserves & $100 \%$ \\
\hline 3.B & Goodwill & $100 \%$ & 5 & Other reserves & $100 \%$ \\
\hline 3.C & Other intangibles & $100 \%$ & & & \\
\hline 3.D & Other assets & $100 \%$ & 6 & Equity & $100 \%$ \\
\hline
\end{tabular}




\section{Table 1 Summary statistics}

Notes: Non-deposit liabilities are defined as (total liabilities minus total deposits) divided by total liabilities. Nondeposit funding is the ratio of (total finding minus total deposits) to total funding. The NSFR is computed in line with the Basel III proposal and weights from Vazquez and Federico (2012). Tier 1 and Total regulatory capital are expressed in \% of RWA. Tangible common equity is expressed in \% of total tangible assets. All variables (apart from the log-change in lending, liquid asset ratio, risk profile, and total assets) are winsorized at the 1st and 99th percentiles of the distribution to reduce the impact of extreme observations. All covariates are measured as of 2007Q2 or 2007Q1 if Q2 data are missing. If quarterly data are missing, the variables are measured as the mid-point of 2006 and 2007 data, or as of end-2006. Data sources: Loan Analytics and Bankscope.

\begin{tabular}{lcccccc}
\hline \multicolumn{1}{c}{ Variable } & Obs & Mean & St. Dev. & P5 & P50 & P95 \\
\hline Dependent variable & & & & & & \\
Log-change in lending (x100) & 7,156 & -21.41 & 142.71 & -254.68 & -21.79 & 214.72 \\
Exposure to liquidity shocks (pre-crisis) & & & & & & \\
Non-deposit liabilities & 710 & 32.33 & 26.81 & 1.49 & 23.91 & 86.91 \\
Non-deposit funding & 710 & 29.53 & 26.85 & 0.18 & 20.48 & 86.52 \\
Log-NSFR & 444 & 4.44 & 0.22 & 3.90 & 4.46 & 4.77 \\
Other bank characteristics (pre-crisis) & & & & & & \\
Tier 1 ratio & 607 & 10.01 & 3.67 & 6.09 & 9.10 & 18.98 \\
Total regulatory capital ratio & 618 & 12.46 & 2.89 & 9.04 & 11.51 & 20.10 \\
Tangible common equity ratio & 743 & 6.90 & 4.29 & 2.09 & 6.03 & 16.02 \\
Return on assets & 750 & 0.92 & 0.87 & -0.02 & 0.80 & 2.47 \\
Non-performing loans & 634 & 2.65 & 2.47 & 0.14 & 1.80 & 7.61 \\
Liquid asset ratio & 761 & 17.42 & 15.88 & 2.33 & 11.86 & 47.76 \\
Risk profile (RWA/Total assets) & 556 & 63.65 & 17.90 & 30.76 & 62.53 & 94.38 \\
Total assets (2005 USD bn) & 763 & 119.49 & 304.26 & 1.18 & 20.49 & 708.52 \\
\% change in total assets & 741 & 28.01 & 39.73 & -21.02 & 24.08 & 100.08 \\
\% change in total loans & 694 & 33.16 & 50.52 & -23.03 & 25.14 & 122.06 \\
Type of entity, of which: & & & & & & \\
$\quad$ Branch location & 1 & 0.12 & - & - & - & - \\
Controlled subsidiary & 420 & 52.30 & - & - & - & - \\
Global owner & 251 & 31.26 & - & - & - & - \\
Independent company & 22 & 2.74 & - & - & - & - \\
$\quad$ Single location bank & 109 & 13.57 & - & - & - & - \\
Specialization, of which: & & & & & & - \\
$\quad$ Commercial, cooperative, savings bank & 680 & 84.68 & - & - & - & - \\
Bank holding company & 38 & 4.73 & - & - & - & - \\
Other & 85 & 10.59 & - & - & & \\
\hline
\end{tabular}




\section{Table 2 Correlation matrix}

Notes: Definitions as in Table 1. * indicates significance at 1 percent. Data sources: Loan Analytics and Bankscope.

\begin{tabular}{|c|c|c|c|c|c|c|c|c|c|c|c|}
\hline & $\begin{array}{l}\text { Log-change } \\
\text { in lending }\end{array}$ & $\begin{array}{c}\text { Non- } \\
\text { deposit } \\
\text { liabilities }\end{array}$ & $\begin{array}{l}\text { Non- } \\
\text { deposit } \\
\text { funding }\end{array}$ & $\begin{array}{l}\text { Log- } \\
\text { NSFR }\end{array}$ & Tier 1 & $\begin{array}{c}\text { Total } \\
\text { regulatory } \\
\text { capital } \\
\end{array}$ & $\begin{array}{c}\text { Tangible } \\
\text { common } \\
\text { equity }\end{array}$ & $\begin{array}{l}\text { Return on } \\
\text { assets }\end{array}$ & $\begin{array}{c}\text { Non- } \\
\text { perform- } \\
\text { ing loans }\end{array}$ & $\begin{array}{c}\text { Liquid } \\
\text { asset } \\
\text { ratio } \\
\end{array}$ & $\begin{array}{c}\text { Risk } \\
\text { profile }\end{array}$ \\
\hline Log-change in lending & 1 & & & & & & & & & & \\
\hline \multicolumn{12}{|l|}{ Exposure to liquidity shocks } \\
\hline Non-deposit liabilities & $-0.1264 *$ & 1 & & & & & & & & & \\
\hline Non-deposit funding & $-0.1211 *$ & $0.9932 *$ & 1 & & & & & & & & \\
\hline Log-NSFR & 0.0788 & $-0.3692 *$ & $-0.3984 *$ & 1 & & & & & & & \\
\hline \multicolumn{12}{|l|}{ Capital adequacy } \\
\hline Tier 1 & 0.009 & 0.0342 & 0.0235 & 0.1124 & 1 & & & & & & \\
\hline Total regulatory capital & 0.0210 & 0.0873 & 0.0681 & $0.1508 *$ & $0.8620^{*}$ & 1 & & & & & \\
\hline Tangible common equity & -0.0224 & -0.0021 & -0.0061 & 0.1191 & $0.7385^{*}$ & $0.6693 *$ & 1 & & & & \\
\hline \multicolumn{12}{|l|}{ Other bank characteristics } \\
\hline Return on assets & -0.0317 & $0.1053^{*}$ & 0.0808 & $0.1780 *$ & $0.3853^{*}$ & $0.4127 *$ & $0.5919 *$ & 1 & & & \\
\hline Non-performing loans & $0.1274 *$ & $-0.2471 *$ & $-0.2422 *$ & $0.2094 *$ & -0.0662 & -0.0821 & $-0.1509 *$ & $-0.2128 *$ & 1 & & \\
\hline Liquid asset ratio & -0.0116 & $0.3533^{*}$ & $0.3426^{*}$ & -0.0297 & $0.3024^{*}$ & $0.3548 *$ & 0.0934 & $0.1147 *$ & 0.0552 & 1 & \\
\hline Risk profile (RWA/Total assets) & -0.0638 & $-0.1144 *$ & -0.0994 & -0.0542 & $-0.1698 *$ & $-0.1531 *$ & $0.3385^{*}$ & $0.2776^{*}$ & $-0.2401 *$ & $-0.3574 *$ & 1 \\
\hline Total assets & $-0.1144^{*}$ & $0.2584 *$ & $0.2398 *$ & -0.0792 & $-0.1389 *$ & -0.0542 & $-0.2703^{*}$ & -0.0634 & $-0.1094 *$ & $0.2090^{*}$ & $-0.2992 *$ \\
\hline
\end{tabular}




\section{Table 3 Reliance on wholesale funding and bank lending: Baseline results}

Notes: The dependent variable is the change in log-lending between the "before" and "after" periods (January 2006-June 2007 vs. October 2008-March 2010). Variable definitions as in Table 1. The variable "capital" refers to the tangible common equity ratio. Standard errors are clustered at the bank level. * indicates significance at $10 \%, * *$ at $5 \%$ and $* * *$ at $1 \%$. Data sources: Loan Analytics and Bankscope.

\begin{tabular}{|c|c|c|c|c|c|c|c|c|c|}
\hline (1) & (2) & (3) & (4) & (5) & (6) & $(7)$ & (8) & $(9)$ & (10) \\
\hline \multicolumn{4}{|c|}{ Do not control for demand } & \multicolumn{6}{|c|}{ Control for demand } \\
\hline \multicolumn{2}{|c|}{ Full sample } & \multicolumn{2}{|c|}{ Full sample } & \multicolumn{2}{|c|}{ Full sample } & \multicolumn{2}{|c|}{ Full sample } & \multicolumn{2}{|c|}{ Non-US banks } \\
\hline $\begin{array}{c}-0.926 * * * \\
(0.148)\end{array}$ & & $\begin{array}{c}-0.998 * * * \\
(0.190)\end{array}$ & & $\begin{array}{c}-0.782 * * * \\
(0.186)\end{array}$ & & $\begin{array}{c}-0.897 * * * \\
(0.238)\end{array}$ & & $\begin{array}{c}-0.776 * * * \\
(0.239)\end{array}$ & \\
\hline & $\begin{array}{c}-0.834 * * * \\
(0.138)\end{array}$ & & $\begin{array}{c}-0.910 * * * \\
(0.176)\end{array}$ & & $\begin{array}{c}-0.698 * * * \\
(0.166)\end{array}$ & & $\begin{array}{c}-0.813 * * * \\
(0.214)\end{array}$ & & $\begin{array}{c}-0.722 * * * \\
(0.219)\end{array}$ \\
\hline & & $\begin{array}{c}7.085 \\
(8.690)\end{array}$ & $\begin{array}{c}6.232 \\
(8.626)\end{array}$ & & & $\begin{array}{c}9.106 \\
(9.063)\end{array}$ & $\begin{array}{c}8.372 \\
(9.005)\end{array}$ & $\begin{array}{l}-3.818 \\
(5.844)\end{array}$ & $\begin{array}{l}-4.502 \\
(5.807)\end{array}$ \\
\hline & & -2.462 & -2.051 & & & $-4.287 * *$ & $-3.921 * *$ & $-3.611 *$ & $-3.314^{*}$ \\
\hline & & (1.911) & (1.874) & & & $(2.001)$ & $(1.962)$ & (1.997) & (1.961) \\
\hline & & -0.098 & -0.043 & & & -0.099 & -0.054 & -0.200 & -0.136 \\
\hline & & $(0.310)$ & $(0.315)$ & & & $(0.329)$ & $(0.337)$ & $(0.378)$ & $(0.384)$ \\
\hline & & -0.011 & $-0.012 *$ & & & -0.009 & -0.011 & -0.008 & -0.009 \\
\hline & & (0.007) & $(0.007)$ & & & $(0.007)$ & $(0.007)$ & $(0.007)$ & (0.007) \\
\hline & & -0.375 & -0.303 & & & -0.181 & -0.117 & -0.038 & 0.037 \\
\hline & & $(0.246)$ & $(0.244)$ & & & $(0.259)$ & $(0.259)$ & $(0.284)$ & $(0.285)$ \\
\hline & & -2.280 & -2.292 & & & -1.904 & -1.910 & 0.410 & 0.373 \\
\hline & & (1.552) & (1.544) & & & (1.628) & (1.625) & (1.268) & (1.266) \\
\hline $\begin{array}{c}-0.133 * * \\
(0.054)\end{array}$ & $\begin{array}{c}-0.154 * * * \\
(0.055)\end{array}$ & $\begin{array}{l}-0.098 \\
(0.083)\end{array}$ & $\begin{array}{l}-0.109 \\
(0.085)\end{array}$ & $\begin{array}{c}-0.190 * * \\
(0.074)\end{array}$ & $\begin{array}{c}-0.206 * * * \\
(0.077)\end{array}$ & $\begin{array}{l}-0.143 \\
(0.101)\end{array}$ & $\begin{array}{l}-0.151 \\
(0.103)\end{array}$ & $\begin{array}{l}-0.050 \\
(0.096)\end{array}$ & $\begin{array}{l}-0.058 \\
(0.097)\end{array}$ \\
\hline no & no & no & no & yes & yes & yes & yes & yes & yes \\
\hline yes & yes & yes & yes & yes & yes & yes & yes & yes & yes \\
\hline yes & yes & yes & yes & yes & yes & yes & yes & yes & yes \\
\hline no & no & yes & yes & no & no & yes & yes & yes & yes \\
\hline 6,694 & 6,694 & 5,813 & 5,813 & 6,628 & 6,628 & 5,756 & 5,756 & 4,788 & 4,788 \\
\hline 0.089 & 0.088 & 0.065 & 0.064 & 0.286 & 0.285 & 0.279 & 0.279 & 0.309 & 0.309 \\
\hline
\end{tabular}




\section{Table 4 Reliance on wholesale funding and bank lending: The mitigating impact of capital}

Notes: Variable definitions as in Table 1, dependent variable as in table 3 . The specifications include interaction terms between measures of exposure to liquidity shocks and capital adequacy. The variable "capital" refers to Tier 1 ratio (columns 1-4), total regulatory capital ratio (columns 5-8) and tangible common equity ratio (columns 9-12). Standard errors are clustered at the bank level. * indicates significance at 10\%, ** at 5\% and *** at 1\%. Data sources: Loan Analytics and

Bankscope.

\begin{tabular}{|c|c|c|c|c|c|c|c|c|c|c|c|c|}
\hline & (1) & (2) & (3) & (4) & (5) & (6) & (7) & (8) & (9) & (10) & (11) & (12) \\
\hline & \multicolumn{4}{|c|}{ Tier 1} & \multicolumn{4}{|c|}{ Total regulatory capital } & \multicolumn{4}{|c|}{ Tangible common equity } \\
\hline Non-deposit liabilities & $\begin{array}{c}-1.063 * * \\
(0.460)\end{array}$ & $\begin{array}{c}-1.169 * * \\
(0.481)\end{array}$ & & & $\begin{array}{l}-0.679 \\
(0.695)\end{array}$ & $\begin{array}{l}-1.020 \\
(0.726)\end{array}$ & & & $\begin{array}{c}-1.249 * * * \\
(0.348)\end{array}$ & $\begin{array}{c}-1.392 * * * \\
(0.379)\end{array}$ & & \\
\hline Non-deposit liabilities * Capital & $\begin{array}{c}0.023 \\
(0.035)\end{array}$ & $\begin{array}{c}0.027 \\
(0.040)\end{array}$ & & & $\begin{array}{l}-0.013 \\
(0.050)\end{array}$ & $\begin{array}{c}0.009 \\
(0.054)\end{array}$ & & & $\begin{array}{c}0.076 * * \\
(0.033)\end{array}$ & $\begin{array}{c}0.083 * * \\
(0.040)\end{array}$ & & \\
\hline Non-deposit funding & & & $\begin{array}{c}-0.958 * * \\
(0.436)\end{array}$ & $\begin{array}{c}-1.013 * * \\
(0.451)\end{array}$ & & & $\begin{array}{l}-0.586 \\
(0.667)\end{array}$ & $\begin{array}{l}-0.877 \\
(0.699)\end{array}$ & & & $\begin{array}{c}-1.116^{* * * *} \\
(0.313)\end{array}$ & $\begin{array}{c}-1.202 * * * \\
(0.336)\end{array}$ \\
\hline Non-deposit funding $*$ Capital & & & $\begin{array}{c}0.020 \\
(0.035)\end{array}$ & $\begin{array}{c}0.020 \\
(0.040)\end{array}$ & & & $\begin{array}{l}-0.015 \\
(0.049)\end{array}$ & $\begin{array}{c}0.004 \\
(0.054)\end{array}$ & & & $\begin{array}{c}0.067 * * \\
(0.032)\end{array}$ & $\begin{array}{c}0.068 * \\
(0.039)\end{array}$ \\
\hline Return on assets & & $\begin{array}{c}6.195 \\
(9.522)\end{array}$ & & $\begin{array}{c}5.679 \\
(9.450)\end{array}$ & & $\begin{array}{c}5.361 \\
(9.185)\end{array}$ & & $\begin{array}{c}4.973 \\
(9.059)\end{array}$ & & $\begin{array}{c}4.409 \\
(9.977)\end{array}$ & & $\begin{array}{c}4.590 \\
(9.851)\end{array}$ \\
\hline Non-performing loans & & $\begin{array}{c}-4.617 * * \\
(1.966)\end{array}$ & & $\begin{array}{c}-4.151 * * \\
(1.937)\end{array}$ & & $\begin{array}{c}-4.301 * * \\
(1.997)\end{array}$ & & $\begin{array}{c}-3.882^{* *} \\
(1.975)\end{array}$ & & $\begin{array}{c}-5.359 * * * \\
(1.906)\end{array}$ & & $\begin{array}{c}-4.697 * * \\
(1.879)\end{array}$ \\
\hline Liquid asset ratio & & $\begin{array}{l}-0.182 \\
(0.324)\end{array}$ & & $\begin{array}{l}-0.127 \\
(0.333)\end{array}$ & & $\begin{array}{l}-0.187 \\
(0.323)\end{array}$ & & $\begin{array}{l}-0.131 \\
(0.332)\end{array}$ & & $\begin{array}{l}-0.160 \\
(0.324)\end{array}$ & & $\begin{array}{l}-0.096 \\
(0.334)\end{array}$ \\
\hline Total assets & & $\begin{array}{l}-0.008 \\
(0.008)\end{array}$ & & $\begin{array}{l}-0.009 \\
(0.007)\end{array}$ & & $\begin{array}{l}-0.007 \\
(0.007)\end{array}$ & & $\begin{array}{l}-0.009 \\
(0.007)\end{array}$ & & $\begin{array}{l}-0.008 \\
(0.007)\end{array}$ & & $\begin{array}{l}-0.010 \\
(0.007)\end{array}$ \\
\hline Risk profile & $\begin{array}{l}-0.032 \\
(0.267)\end{array}$ & $\begin{array}{l}-0.222 \\
(0.285)\end{array}$ & $\begin{array}{c}0.034 \\
(0.264)\end{array}$ & $\begin{array}{l}-0.143 \\
(0.287)\end{array}$ & $\begin{array}{c}0.008 \\
(0.256)\end{array}$ & $\begin{array}{l}-0.139 \\
(0.263)\end{array}$ & $\begin{array}{c}0.063 \\
(0.253)\end{array}$ & $\begin{array}{l}-0.074 \\
(0.264)\end{array}$ & $\begin{array}{l}-0.136 \\
(0.255)\end{array}$ & $\begin{array}{l}-0.242 \\
(0.255)\end{array}$ & $\begin{array}{l}-0.064 \\
(0.253)\end{array}$ & $\begin{array}{l}-0.160 \\
(0.257)\end{array}$ \\
\hline Capital & $\begin{array}{l}-0.247 \\
(2.003)\end{array}$ & $\begin{array}{l}-1.418 \\
(2.096)\end{array}$ & $\begin{array}{c}0.012 \\
(1.946)\end{array}$ & $\begin{array}{l}-1.060 \\
(2.060)\end{array}$ & $\begin{array}{c}2.146 \\
(2.310)\end{array}$ & $\begin{array}{c}0.396 \\
(2.422)\end{array}$ & $\begin{array}{c}2.031 \\
(2.277)\end{array}$ & $\begin{array}{c}0.421 \\
(2.408)\end{array}$ & $\begin{array}{c}-4.113 * \\
(2.118)\end{array}$ & $\begin{array}{c}-5.059 * * \\
(2.073)\end{array}$ & $\begin{array}{c}-3.547 * \\
(2.029)\end{array}$ & $\begin{array}{c}-4.307 * * \\
(2.017)\end{array}$ \\
\hline No. borrowers per bank & $\begin{array}{c}-0.166^{*} \\
(0.088)\end{array}$ & $\begin{array}{l}-0.129 \\
(0.099)\end{array}$ & $\begin{array}{c}-0.182 * * \\
(0.091)\end{array}$ & $\begin{array}{l}-0.138 \\
(0.101)\end{array}$ & $\begin{array}{c}-0.171 * * \\
(0.087)\end{array}$ & $\begin{array}{l}-0.123 \\
(0.099)\end{array}$ & $\begin{array}{c}-0.187 * * \\
(0.089)\end{array}$ & $\begin{array}{l}-0.133 \\
(0.101)\end{array}$ & $\begin{array}{c}-0.187 * * \\
(0.091)\end{array}$ & $\begin{array}{l}-0.144 \\
(0.098)\end{array}$ & $\begin{array}{c}-0.207 * * \\
(0.094)\end{array}$ & $\begin{array}{l}-0.154 \\
(0.100)\end{array}$ \\
\hline Borrower fixed effects & yes & yes & yes & yes & yes & yes & yes & yes & yes & yes & yes & yes \\
\hline Lender nationality fixed effects & yes & yes & yes & yes & yes & yes & yes & yes & yes & yes & yes & yes \\
\hline Lender type and specialization & yes & yes & yes & yes & yes & yes & yes & yes & yes & yes & yes & yes \\
\hline Other lender controls & no & yes & no & yes & no & yes & no & yes & no & yes & no & yes \\
\hline Observations & 6,051 & 6,014 & 6,051 & 6,014 & 6,051 & 6,014 & 6,051 & 6,014 & 5,793 & 5,756 & 5,793 & 5,756 \\
\hline R-squared & 0.277 & 0.280 & 0.277 & 0.279 & 0.277 & 0.280 & 0.277 & 0.279 & 0.277 & 0.280 & 0.277 & 0.279 \\
\hline
\end{tabular}




\section{Table 5 Structural liquidity (NSFR) and bank lending}

Notes: Variable definitions as in Table 1, dependent variable as in table 3. In columns 3-11 the sample is split in subsamples of banks by level of capitalization ("high" refers to above-median capital). For the low-capital subsample we do not report results without controls as they are similar to those with controls. In the baseline regressions (column 2), the variable "capital" refers to the tangible common equity ratio. Standard errors are clustered at the bank level. * indicates significance at $10 \%, * *$ at $5 \%$ and $* * *$ at $1 \%$. Data sources: Loan Analytics and Bankscope.

\begin{tabular}{|c|c|c|c|c|c|c|c|c|c|c|c|}
\hline & $(1)$ & $(2)$ & (3) & (4) & $(5)$ & $(6)$ & $(7)$ & $(8)$ & (9) & $(10)$ & $(11)$ \\
\hline & & & \multicolumn{3}{|c|}{ Tier 1} & \multicolumn{3}{|c|}{ Total regulatory capital } & \multicolumn{3}{|c|}{ Tangible common equity } \\
\hline & \multicolumn{2}{|c|}{ Full sample } & \multicolumn{2}{|c|}{ High } & \multirow{2}{*}{$\begin{array}{c}\text { Low } \\
\\
21.005 \\
(38.805)\end{array}$} & \multicolumn{2}{|c|}{ High } & \multirow{2}{*}{$\begin{array}{c}\text { Low } \\
\\
34.616 \\
(46.585)\end{array}$} & \multicolumn{2}{|c|}{ High } & Low \\
\hline Log-NSFR & $\begin{array}{c}43.083^{* *} \\
(21.281)\end{array}$ & $\begin{array}{l}46.214 * \\
(27.901)\end{array}$ & $\begin{array}{c}57.844 \\
(38.078)\end{array}$ & $\begin{array}{l}98.733 * \\
(54.794)\end{array}$ & & $\begin{array}{c}37.520 \\
(35.736)\end{array}$ & $\begin{array}{c}26.091 \\
(39.829)\end{array}$ & & $\begin{array}{c}88.047 * * \\
(39.270)\end{array}$ & $\begin{array}{c}138.293 * \\
(72.120)\end{array}$ & $\begin{array}{c}49.995 \\
(36.491)\end{array}$ \\
\hline Return on assets & & $\begin{array}{c}2.609 \\
(10.111)\end{array}$ & & $\begin{array}{c}-1.918 \\
(10.608)\end{array}$ & $\begin{array}{c}15.488 \\
(14.242)\end{array}$ & & $\begin{array}{c}4.231 \\
(11.805)\end{array}$ & $\begin{array}{c}33.488 * * * \\
(12.796)\end{array}$ & & $\begin{array}{c}7.592 \\
(14.286)\end{array}$ & $\begin{array}{c}-0.993 \\
(14.585)\end{array}$ \\
\hline Non-performing loans & & $\begin{array}{c}-4.238 * \\
(2.311)\end{array}$ & & $\begin{array}{c}2.203 \\
(4.537)\end{array}$ & $\begin{array}{c}0.982 \\
(3.661)\end{array}$ & & $\begin{array}{l}-6.862 \\
(4.541)\end{array}$ & $\begin{array}{c}3.311 \\
(5.102)\end{array}$ & & $\begin{array}{c}3.300 \\
(4.827)\end{array}$ & $\begin{array}{l}-4.002 \\
(2.734)\end{array}$ \\
\hline Liquid asset ratio & & $\begin{array}{l}-0.419 \\
(0.363)\end{array}$ & & $\begin{array}{c}1.206 \\
(0.789)\end{array}$ & $\begin{array}{l}-0.170 \\
(0.563)\end{array}$ & & $\begin{array}{c}0.328 \\
(0.551)\end{array}$ & $\begin{array}{c}-1.064 * \\
(0.598)\end{array}$ & & $\begin{array}{c}1.385 \\
(0.990)\end{array}$ & $\begin{array}{c}-0.724 * \\
(0.400)\end{array}$ \\
\hline Total assets & & $\begin{array}{c}-0.012 * \\
(0.007)\end{array}$ & & $\begin{array}{c}-0.094 * * * \\
(0.031)\end{array}$ & $\begin{array}{l}-0.008 \\
(0.009)\end{array}$ & & $\begin{array}{l}-0.023 \\
(0.014)\end{array}$ & $\begin{array}{c}-0.019 * * \\
(0.008)\end{array}$ & & $\begin{array}{l}-0.014 \\
(0.141)\end{array}$ & $\begin{array}{c}-0.016^{* * *} \\
(0.007)\end{array}$ \\
\hline Risk profile & & $\begin{array}{c}0.043 \\
(0.320)\end{array}$ & & $\begin{array}{l}-0.269 \\
(0.814)\end{array}$ & $\begin{array}{c}0.184 \\
(0.448)\end{array}$ & & $\begin{array}{l}-0.060 \\
(0.515)\end{array}$ & $\begin{array}{l}-0.406 \\
(0.421)\end{array}$ & & $\begin{array}{c}0.432 \\
(0.734)\end{array}$ & $\begin{array}{l}-0.689 \\
(0.427)\end{array}$ \\
\hline Capital & & $\begin{array}{l}-0.542 \\
(1.929)\end{array}$ & & & & & & & & & \\
\hline No. borrowers per bank & $\begin{array}{c}-0.243^{* * *} \\
(0.087)\end{array}$ & $\begin{array}{l}-0.132 \\
(0.106)\end{array}$ & $\begin{array}{l}-0.285 \\
(0.473)\end{array}$ & $\begin{array}{l}-0.016 \\
(0.549)\end{array}$ & $\begin{array}{l}-0.106 \\
(0.135)\end{array}$ & $\begin{array}{l}-0.298 \\
(0.206)\end{array}$ & $\begin{array}{l}-0.202 \\
(0.315)\end{array}$ & $\begin{array}{l}-0.159 \\
(0.106)\end{array}$ & $\begin{array}{c}-3.119 * * \\
(1.243)\end{array}$ & $\begin{array}{c}-4.407 * * \\
(1.751)\end{array}$ & $\begin{array}{l}-0.072 \\
(0.104)\end{array}$ \\
\hline Borrower fixed effects & yes & yes & yes & yes & yes & yes & yes & yes & yes & yes & yes \\
\hline Lender nationality fixed effects & yes & yes & yes & yes & yes & yes & yes & yes & yes & yes & yes \\
\hline Lender type and specialization & yes & yes & yes & yes & yes & yes & yes & yes & yes & yes & yes \\
\hline Other lender controls & no & yes & no & yes & yes & no & yes & yes & no & yes & yes \\
\hline Observations & 4,249 & 3,686 & 903 & 814 & 2,876 & 1,705 & 1,599 & 2,091 & 852 & 651 & 3,035 \\
\hline R-squared & 0.322 & 0.330 & 0.492 & 0.513 & 0.348 & 0.416 & 0.422 & 0.402 & 0.479 & 0.496 & 0.362 \\
\hline
\end{tabular}




\section{Figure 6 Partial correlation plots}

Notes: The panels represent partial correlation plots for the wholesale funding and NSFR variables based on, respectively, the estimates from Table 3 column 5 and Table 5 column 1. Variable definitions as in Table 1. Data sources: Loan Analytics and Bankscope.

\section{A. Non-deposit liabilities}

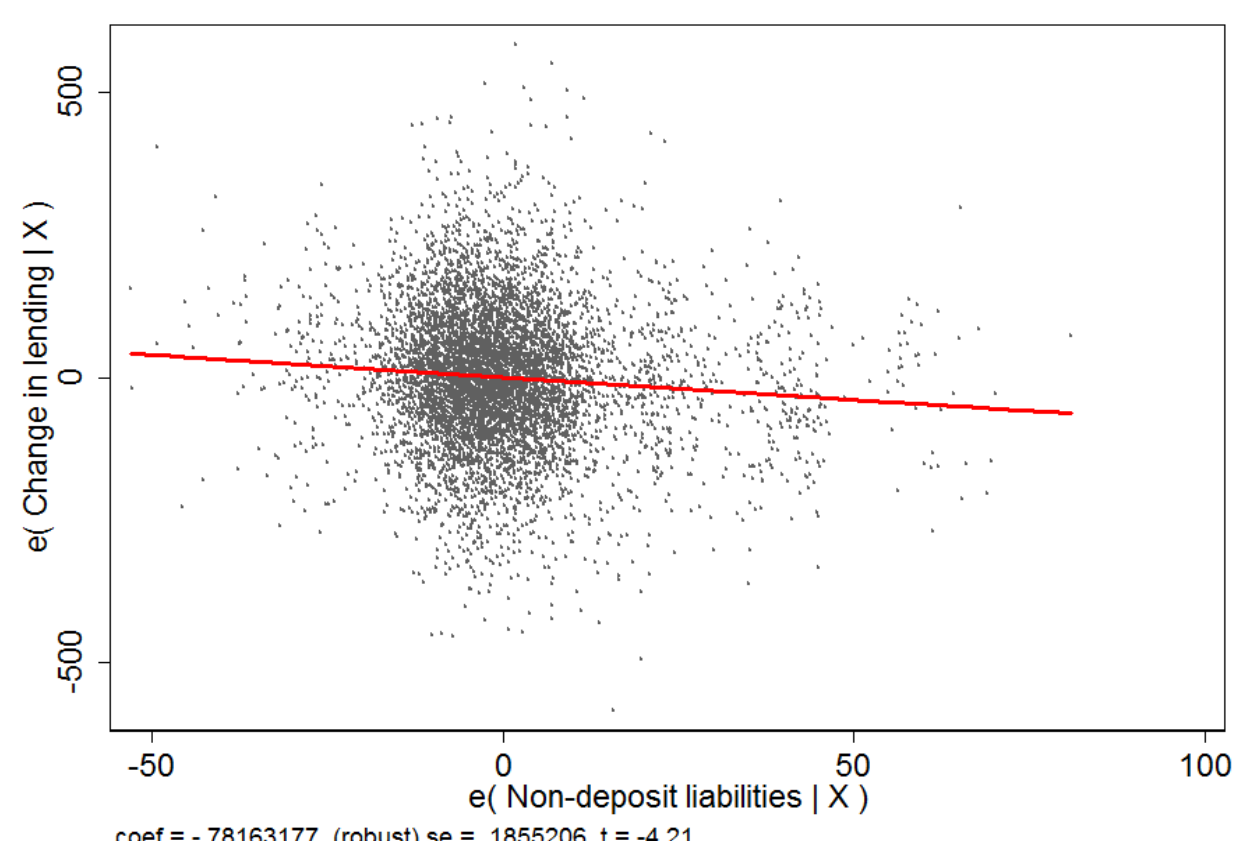

B. Log-NSFR

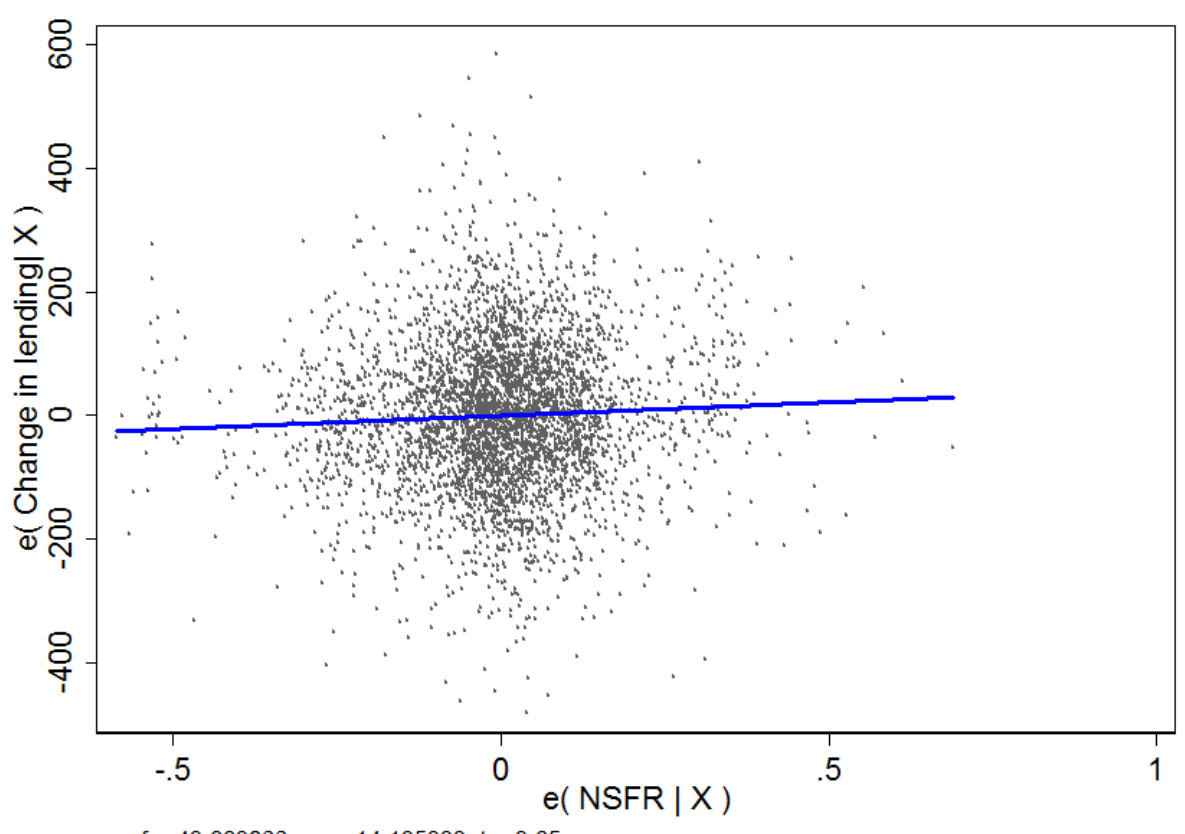

coef $=43.083266$, se $=14.135333, t=3.05$ 


\section{Table 6 Robustness checks}

Notes: Variable definitions as in Table 1, dependent variable as in table 3. Compared to previous specifications, we add controls such as the \% change in total loans (columns 1-7) and the \% change in total assets (columns 8-14) between the "before" and "after" periods. The variable "capital" refers to the tangible common equity ratio. In columns 6-7 and 13-14 the sample is split in subsamples of banks by level of capitalization ("high" refers to above-median tangible common equity ratio). All regressions include borrower fixed effects, lender nationality fixed effects, dummies for lender type and specialization (coefficients not shown), and other lender controls (coefficients shown). Standard errors are clustered at the bank level. * indicates significance at $10 \%$, \# at $15 \%$, ** at 5\% and *** at $1 \%$. Data sources: Loan Analytics and Bankscope.

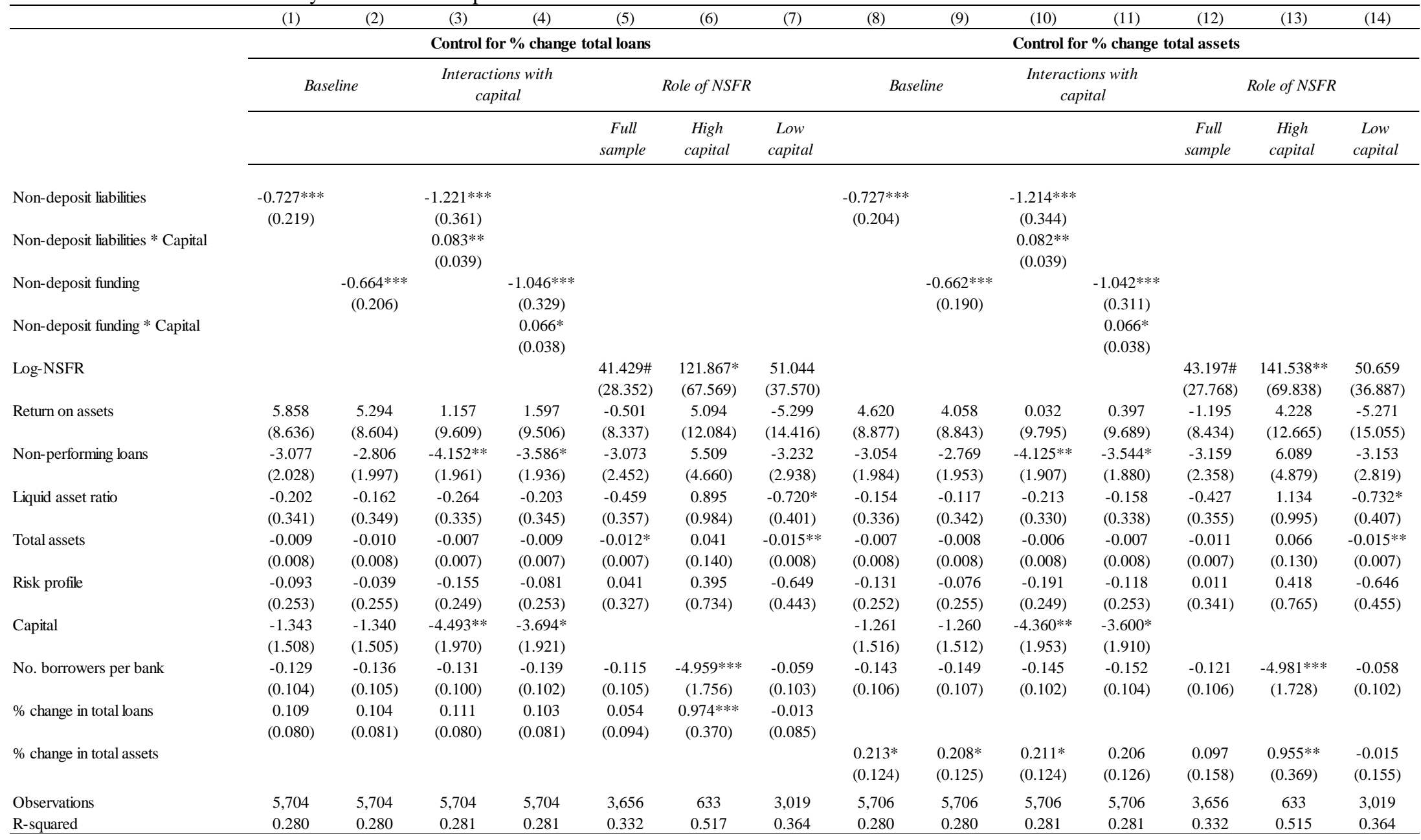




\section{DAta APPEndix}

Here we provide detail on our data sources and data transformations carried out to obtain the baseline regression sample. ${ }^{25}$

Data sources: Syndicated loan-level data comes from the Loan Analytics (LA) database provided by Dealogic. We started with 39,626 syndicated loan deals signed between January 1, 2006 and March 31, 2010. We drop the deals for which the lender is recorded as "unknown," "undisclosed syndicate," or "undisclosed investor." We retain the 38,538 loan deals for which the loan amount is non-missing. Loan amounts are reported in USD (for nonUSD loans, the USD amount is calculated using the exchange rate prevailing at the time of deal signing).

Variables and clean-up: For lender (bank) nationality we use the LA variable "Lender nationality." When lender nationality is missing, we impute it after cross-checking with other deals where the bank appears as a lender and has a reported nationality, with bank information from Bankscope, and online sources. For offshore branches we impute the nationality of the onshore bank if there is one. For borrower nationality we use the LA variable "Deal nationality."

To prepare the data for merging with balance sheet information from Bankscope, we uniformize the bank names recorded in LA. This is necessary because the raw data do not always record the bank names consistently or refer to banks that have changed name, have been acquired or have merged with other institutions during the period of analysis.

We utilize the following websites to determine the institutional history of banks:

- official websites of individual banks,

- the National Information Center of the Federal Reserve System (http://www.ffiec.gov/nicpubweb/nicweb/SearchForm.aspx),

- Bloomberg Businessweek (http://investing.businessweek.com/research/company/overview/overview.asp).

We make the following corrections:

- If a bank changed its name during 2006-2010Q1, we retain its name as reported in Bankscope (as of 2012Q1);

- If two or more banks merged during 2006-2010Q1 into a new bank, they are kept as distinct banks until the year of the merger; the bank resulting from the merger is kept thereafter;

- If a bank was acquired by another bank, we keep it as a distinct bank until the year of the acquisition.

\footnotetext{
${ }^{25}$ This section partly draws on the online data appendix of Kapan and Minoiu (2012).
} 
Lender balance sheet information: After uniformizing the lender names and restricting the sample to the borrowers (i.e., country-specific industries) that borrow in the syndicated lending market both before and after the shock window (2007Q3-2008Q3) from at least two distinct financial institutions, we are left with 24,082 deals. We collapse the dataset at the bank-industry level by summing up the amount of loans from each bank to each countryspecific industry during the pre- and post-shock period.

We then merge the syndicated lending data with lenders' balance sheet information. Note that the LA and Bankscope databases do not contain a common unique identifier. For this reason, we perform the matching based on lender name and nationality. For almost 40 percent of the 853 lenders we have an exact match between the two datasets. For the remaining lenders, we perform the matching manually in order to minimize errors. Bank subsidiaries and branches are kept in the dataset so long as they report balance sheet information in Bankscope. Note that we do not link subsidiaries to balance sheet information of their parent companies. After the merge, we have 853 banks lending to firms from 448 country-specific industries in 48 countries. We further remove lenders that are multilateral government banks (e.g., EBRD, Asian Development Bank, IFC, etc.), specialized government credit institutions, and two Islamic banks. The final sample further shrinks to 803 banks - the sample size reported in the paper-due to missing information on balance sheet variables.

Bankscope variables. Most balance sheet variables come from the "Universal bank model" section of Bankscope-a global representation of the raw data which places all the accounting systems on a uniform basis (Fitch Ratings and Bureau van Dijk, 2009). The raw data are financial statements based on the International Financial Reporting Standards (IFRS) when available and on the Generally Accepted Accounting Principles (GAAP) for US banks. The uniformization of variable definitions for the "Universal bank model" template facilitates global comparisons, especially in the recent years that are the focus of our analysis. Over 90 percent of the world's largest 1,000 banks report to Bankscope. ${ }^{26}$ Below we describe the computation of our main variables:

- Non-deposit liabilities: (Total liabilities - total customer deposits)/Total liabilities

- Non-deposit funding: (Total funding - total customer deposits)/Total funding.

- Tier 1 ratio: as reported in Bankscope

- Total regulatory capital ratio: as reported in Bankscope

- Tangible common equity ratio: as reported in Bankscope

- Return on assets: Return on average assets (ROAA) (as reported in Bankscope)

- Non-performing loans: Impaired loans / Gross loans (as reported in Bankscope)

- Liquid asset ratio: Liquid assets / Total assets

- Risk-weighted assets (RWA): Not directly available in Bankscope. Computed from the Tier 1 regulatory ratio and Tier 1 regulatory capital variables.

- Total loans: Gross loans (as reported in Bankscope)

- Variables used for computing the NSFR: as reported in Bankscope

\footnotetext{
${ }^{26}$ For a country-level breakdown of coverage, see Longaberger (2011).
} 


\section{List of borrower countries: ${ }^{27}$}

Advanced Economies are defined according to the IMF's 2010 World Economic Outlook and include Australia, Austria, Belgium, Canada, Croatia, Czech Republic, Denmark, Finland, France, Germany, Greece, Hong Kong SAR, Ireland, Italy, Japan, Luxembourg, Malta*, The Netherlands, New Zealand, Norway, Portugal, Singapore, Slovenia, South Korea, Spain, Sweden, Switzerland, Taiwan Province of China, United Kingdom, and United States.

Emerging Market Economies are defined according to the FTSE advanced and secondary emerging market country list and include Argentina*, Brazil, Chile*, China, Colombia*, Egypt, Hungary, India, Indonesia, Malaysia, Mexico, Morocco*, Pakistan*, Peru, Philippines, Poland, Russian Federation, South Africa, Thailand*, Turkey, United Arab Emirates.

Borrowing Country-specific Industries include (in parentheses the $\%$ of syndicated loan volume obtained in 2007): aerospace (0.71); agribusiness (0.27); auto/truck (3.34); chemicals (3.26); computers and electronics (5.32); construction and building (including real estate/property; 11.46); consumer products (3.09); defense (0.15), finance (13.27); food and beverages (3.47); forestry and paper (1.57); government (0.49); healthcare (6.39); holding companies (1.06); leisure and recreation (3.31); machinery (2.16); metal and steel (2.74); mining (10.04); professional services (3.14); publishing (2.01), retail (4.02); telecommunications (5.44); textiles (0.40); transportation (5.10); and utility and energy (7.80).

List of lender countries: Australia, Austria, Bahrain, Bangladesh, Belgium, Brazil, Canada, China, Croatia, Czech Republic, Denmark, Egypt, Finland, France, Germany, Greece, Hong Kong SAR, Hungary, India, Indonesia, Ireland, Israel, Italy, Japan, Jersey, Jordan, Luxembourg, Macao SAR, Malaysia, Malta, Mexico, The Netherlands, Norway, Pakistan, Peru, Philippines, Poland, Portugal, Qatar, Russian Federation, Saudi Arabia, Singapore, South Africa, South Korea, Spain, Sweden, Switzerland, Taiwan Province of China, Thailand, Turkey, United Arab Emirates, United Kingdom, and United States.

Empirical model for estimating bank-level loans shares: For about 70 percent of the loans in our sample, LA does not report the individual shares contributed by each syndicate member. We impute these shares based on a regression model estimated on the available 30 percent of loan observations ( $\mathrm{N}=100,938$ individual shares):

$$
\ln \left(s_{i j k t}\right)=X_{1 i} \beta_{1}+X_{2 j} \beta_{2}+X_{3 k} \beta_{3}+X_{4 t} \beta_{4}+\varepsilon_{i j k t}
$$

where $\ln \left(s_{i j k t}\right)$ are the log-shares contributed to each loan $i$ signed at time $t$ between borrower $j$ and bank $k$. The regressors include:

\footnotetext{
${ }^{27}$ Borrowers from the countries marked with an asterisk $(*)$ are not present in the final regression sample due to the restrictions applied to implement the identification strategy.
} 
- $\quad X_{1 i}$ : log-loan amount, dummies for loan currency and number of lenders in each loan;

- $X_{2 j}$ : borrower nationality and borrower industry dummies;

- $X_{3 k}$ : lender role (mandated arranger/arranger/bookrunner/participant) and lender nationality dummies;

- $X_{4 t}$ : year-quarter dummies.

The model has an adjusted R-squared of 74 percent. Kernel density estimates of the distributions of in-sample actual vs. predicted shares are shown below:

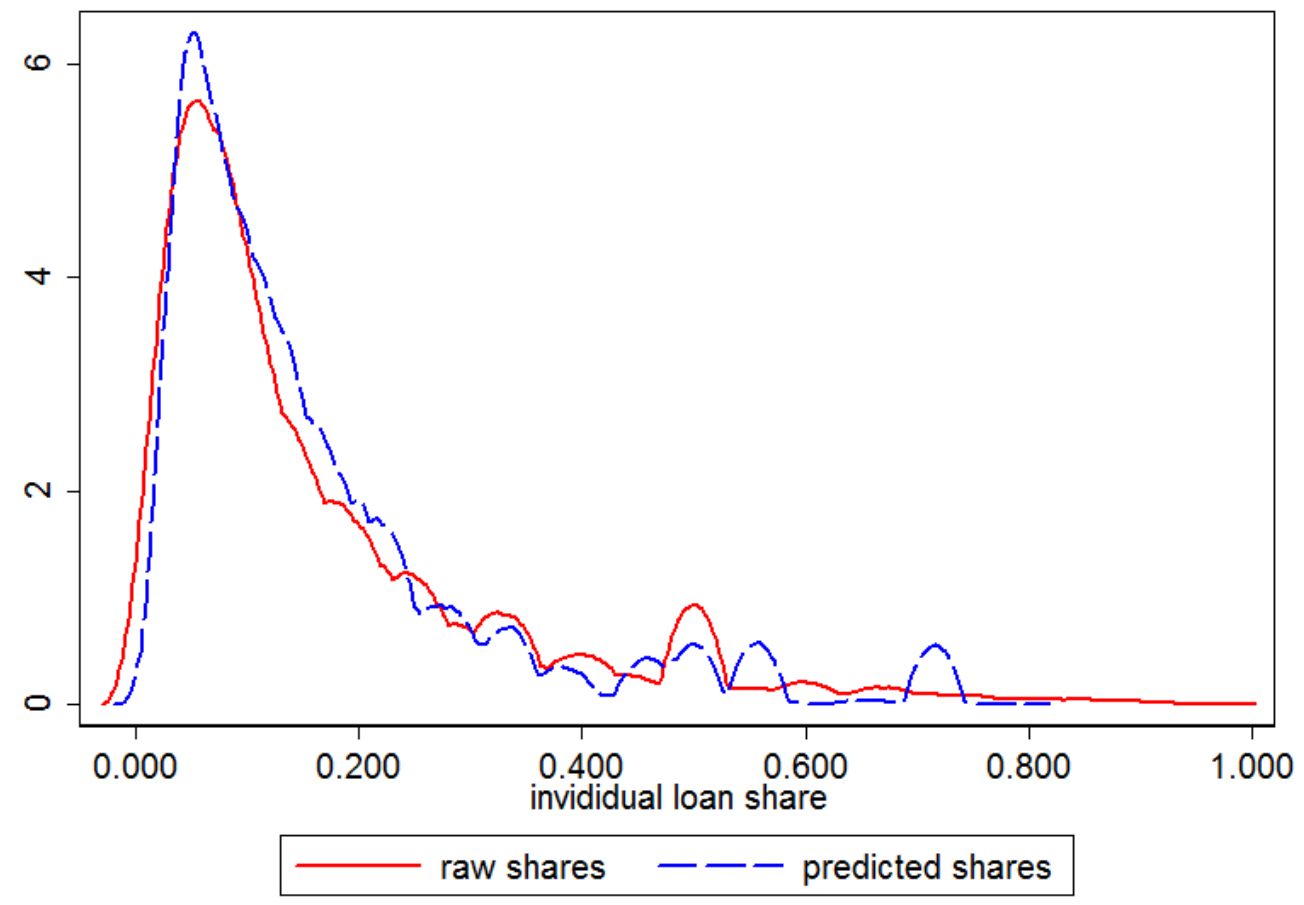

We then use the coefficients of the model to predict the shares out of sample, re-scale them so that they add up to 100 percent for each loan, and multiply them by the total loan amount to obtain the predicted loan amounts for each syndicate member. The final dataset is constructed using actual shares for 30 percent of the loans, and predicted shares for the remaining loans. 